\title{
In defense of magnetite-ilmenite thermometry in the Bishop Tuff and its implication for gradients in silicic magma reservoirs
}

\author{
Bernard W. Evans ${ }^{1}$, Wes Hildreth ${ }^{2}$, Olivier BaChManN ${ }^{3}$, AND Bruno Scaillet ${ }^{4}$ \\ ${ }^{1}$ Department of Earth and Space Sciences, University of Washington, Seattle, Washington 98195-1310, U.S.A. \\ ${ }^{2}$ U.S. Geological Survey, 345 Middlefield Road, Menlo Park, California 94025, U.S.A. \\ ${ }^{3}$ Institute of Geochemistry and Petrology, Department of Earth Sciences, ETH Zurich, Clausiusstrasse 25, 8092 Zurich, Switzerland \\ ${ }^{4}$ Institut de Sciences de la Terre d'Orléans, CNRS-Université d'Orléans-BRGM, UMR 7327, 1A Rue de la Férollerie, 45100 Orléans, France
}

\begin{abstract}
Despite claims to the contrary, the compositions of magnetite and ilmenite in the Bishop Tuff correctly record the changing conditions of $T$ and $f_{\mathrm{O}_{2}}$ in the magma reservoir. In relatively reduced $(\Delta \mathrm{NNO}<1)$ siliceous magmas (e.g., Bishop Tuff, Taupo units), Ti behaves compatibly $\left(\mathrm{D}_{\mathrm{Ti}} \approx 2-3.5\right)$, leading to a decrease in $\mathrm{TiO}_{2}$ activity in the melt with cooling and fractionation. In contrast, FeTioxides are poorer in $\mathrm{TiO}_{2}$ in more oxidized magmas ( $\triangle \mathrm{NNO}>1$, e.g., Fish Canyon Tuff, Pinatubo), and the $d\left(a \mathrm{TiO}_{2}\right) / d T$ slope can be negative. Biotite, FeTi-oxides, liquid, and possibly plagioclase largely maintained equilibrium in the Bishop Tuff magma (unlike the pyroxenes, and cores of quartz, sanidine, and zircon) prior to and during a mixing event triggered by a deeper recharge, which, based on elemental diffusion profiles in minerals, took place at least several decades before eruption. Equilibrating phases and pumice compositions show evolving chemical variations that correlate well with mutually consistent temperatures based on the FeTi-oxides, sanidine-plagioclase, and $\Delta^{18} \mathrm{O}$ quartz-magnetite pairs. Early Bishop Tuff (EBT) temperatures are lower $\left(700\right.$ to $\sim 780^{\circ} \mathrm{C}$ ) than temperatures (780 to $>820^{\circ} \mathrm{C}$ ) registered in Late Bishop Tuff (LBT), the latter defined here not strictly stratigraphically, but by the presence of orthopyroxene and reverse-zoned rims on quartz and sanidine. The claimed similarity in compositions, $\mathrm{Zr}$-saturation temperatures and thermodynamically calculated temperatures $\left(730-740{ }^{\circ} \mathrm{C}\right.$ ) between EBT and less evolved LBT reflect the use of glass inclusions in quartz cores in LBT that were inherited from the low-temperature rhyolitic part of the reservoir characteristic of the EBT. LBT temperatures as high as $820^{\circ} \mathrm{C}$, the preservation of orthopyroxene, and the presence of reverse-zoned minerals (quartz, sanidine, zircons) are consistent with magma recharge at the base of the zoned reservoir, heating the cooler rhyolitic melt, partly remelting cumulate mush, and introducing enough $\mathrm{CO}_{2}(0.4-1.4 \mathrm{wt} \%$, mostly contained in the exsolved fluid phase) to significantly lower $\mathrm{H}_{2} \mathrm{O}$-activity in the system.
\end{abstract}

Keywords: Bishop Tuff, ilmenite-magnetite thermometry, $\mathrm{TiO}_{2}$ activity, reduced magmas, "bright rims", melt inclusions, magma recharge, $\mathrm{CO}_{2}$ effect

\section{INTRODUCTION}

Among large-volume silicic eruptions, the Bishop Tuff(Long Valley caldera, California) has received unusual attention from workers interested in issues such as magma chamber dimensions, longevity, temperatures, depths, compositions, differentiation processes, magma mixing, and eruption history (dozens of papers since Hildreth 1977, 1979, 1981). Nonetheless, controversy remains with regard to the pre-eruption temperature gradient of the Bishop Tuff magma. Taken at face value the ilmenitemagnetite thermometer records a continuous span in temperature from about 700 to $820^{\circ} \mathrm{C}$ and in $f_{\mathrm{O}_{2}}$ from $\triangle \mathrm{NNO}=-0.5$ to +0.5 $\log$ units (Hildreth and Wilson 2007; Ghiorso and Evans 2008), between respectively highly evolved, crystal-poor rhyolitic pumice and less evolved, crystal-rich pumice. The accuracy of these temperatures has been challenged in several communications (Frost and Lindsley 1991, 1992; Ghiorso and Sack 1991; Lindsley et al. 1991; Ghiorso and Evans 2008), and most recently by Ghiorso and Gualda (2013), Gualda and Ghiorso (2013b), and Gardner et al. (2014). These authors have concluded that ilmenite was not everywhere in equilibrium with the magnetite, so that the compositions of the oxide pair do not accurately preserve a record of intensive variables such as pre-eruptive $T$ and $f_{\mathrm{O}_{2}}$ in the magma reservoir.

There is scarcely any more important parameter needed for an enlightened understanding of a giant volcanic system than the spatial and temporal variation of temperature in the magma chamber, as customarily witnessed by the erupted and quenched products. We will try to show in this paper that the widely used FeTi-oxide thermobarometer is reliably linked to Bishop Tuff magma-chamber conditions, supported as it is by $\Delta^{18} \mathrm{O}$ quartzmagnetite, two-feldspar, and Zr-saturation thermometry, and laboratory phase-equilibrium constraints. Our view is consistent with the early classical studies of the Bishop Tuff by Wes Hildreth as well as several recent contributions (Hildreth and Wilson 2007; Wark et al. 2007; Evans and Bachmann 2013; Roberge et al. 2013; Chamberlain et al. 2014a, 2014b, 2015). 


\section{COMPOSITIONAL RANGE OF THE BISHOP TUFF}

\section{Compositional continuity}

About 95\% of the Bishop Tuff consists of a compositional continuum from crystal-poor to crystal-rich rhyolitic pumice, and $\sim 5 \%$ is crystal-poor dark and swirly pumice (Fig. 1). There are also very rare crystal-rich pumices of trachydacite and trachyandesite composition. The more evolved crystal-poor pumice and the less evolved crystal-rich pumice were erupted early and throughout the eruptive sequence in most outflow sectors. The respective stratigraphic predominance of crystal-poor and crystal-rich pumice types led to the simplification early (EBT) vs. late Bishop Tuff (LBT) introduced by Hildreth (1979) as a useful device to contrast the compositional features of the Bishop Tuff array. We stress, however, that it does not reflect a compositional bimodality in magma compositions (Hildreth and Wilson 2007).

The "standard" model for the Bishop Tuff involves sequential eruption from progressively deeper portions of a single compositionally and thermally stratified magma chamber, resulting in inversion of the stratigraphy (Hildreth 1977, 1979; Wilson and Hildreth 1997; Hildreth and Wilson 2007; Roberge et al. 2013; Chamberlain et al. 2015). Gualda and Ghiorso (2013a) challenged this model on the basis of perceived compositional bimodalities and substituted a model involving two magma chambers.

The continuity of geological, mineralogical, and geochemical properties of the Bishop Tuff eruption, and their connection to the eruptive sequence, were summarized in Hildreth and Wilson
(2007). These continua are manifested by progressive changes in pumice-type proportions, crystal content of pumices, major- and trace-element pumice compositions, and mineral and matrixglass compositions (Figs. 2-5). We do not find gaps in plots of these datasets of a magnitude that, given known sampling constraints, would lead us to entertain the idea of eruptions from two (or more) separate reservoirs. Figure 2 typifies the continuity in whole-rock compositions (WR, all from single pumice clasts) for Ti and $\mathrm{Ba}$ in the Bishop Tuff. Likewise, Roberge et al. (2013) demonstrated the compositional continua of matrix glass and melt inclusions across the early/middle/late Bishop Tuff array. In a comprehensive major- and trace-element study of crystals and matrix glass, Chamberlain et al. (2015) reinforce these relationships among phase compositions, sample locations, stratigraphy, and magma evolution.

The idea of bimodality was unintentionally supported by studies that focussed on a small number of samples clearly recognized as early vs. late erupted parts of the sequence (e.g., Anderson et al. 2000). However, the far more abundant sampling tabulated and plotted in Hildreth and Wilson (2007) remedied the apparent data gaps for intermediate WR and FeTi-oxide compositions. For example, the cation ratios $\mathrm{Mg} /(\mathrm{Mg}+\mathrm{Fe})$ of the two FeTi-oxides (Fig. 3) vary continuously across the "main suite" (which contains the "normal" as distinct from the "variant" pumice type, Hildreth and Wilson 2007, Table 1) and coherently with each other (Evans and Bachmann 2013). Frequency maxima (Fig. 3) close to the evolved low- $X_{\mathrm{Mg}}$ (and low- $T$ ) extremes are also a feature of the WR compositions
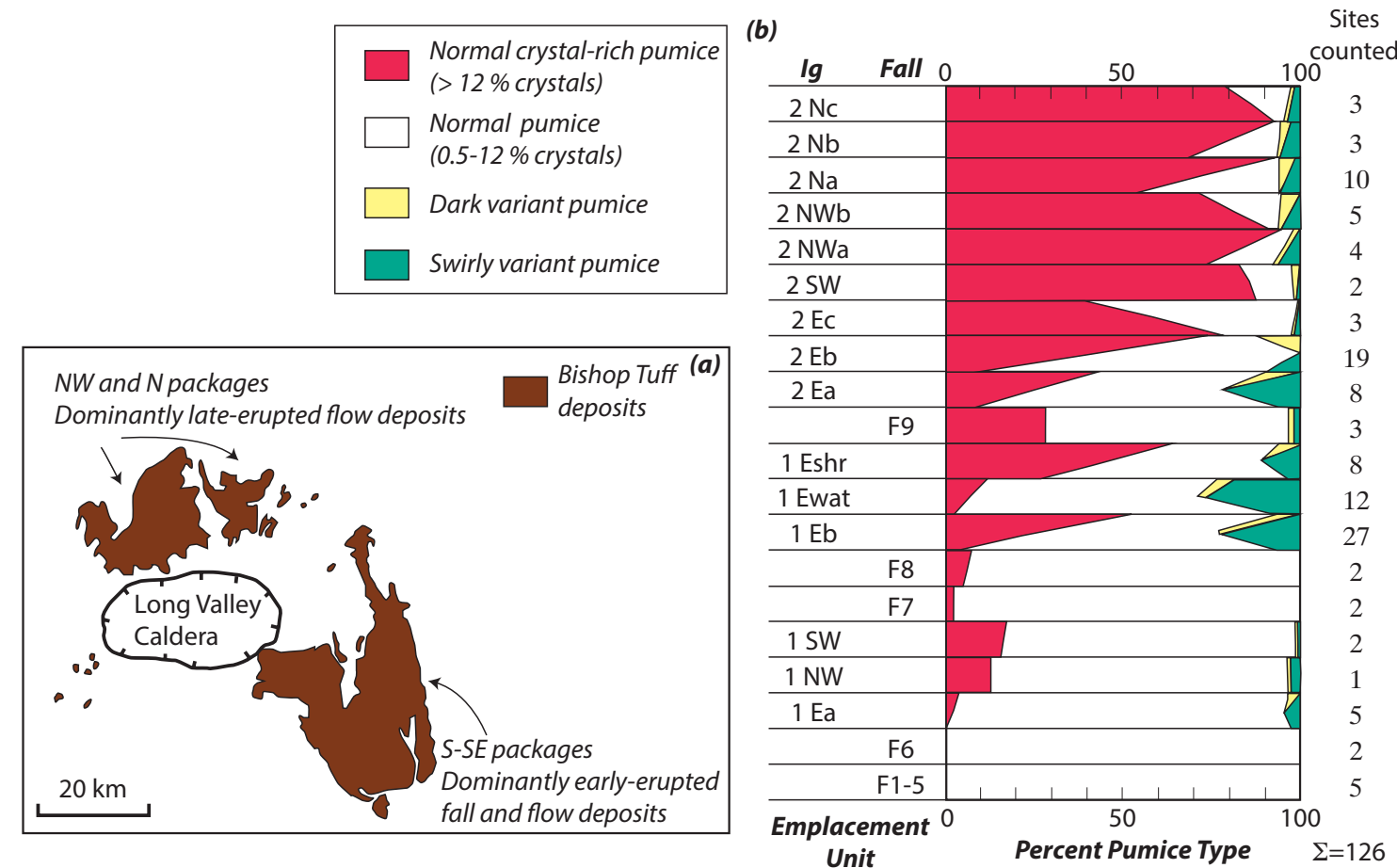

FIGURE 1. (a) Simpified map and packages of deposits in the Bishop Tuff. The SW cluster of glaciated remnants includes superimposed packages of both Ig1SW and Ig2SW. (b) Pumice clast proportions of the different Bishop Tuff emplacement units. Diagonal lines indicate ranges in deposits. The succession of emplacement units (Ig, ignimbrite package; F, fall unit) is detailed in Hildreth and Wilson (2007). Modified from Hildreth and Wilson (2007). 


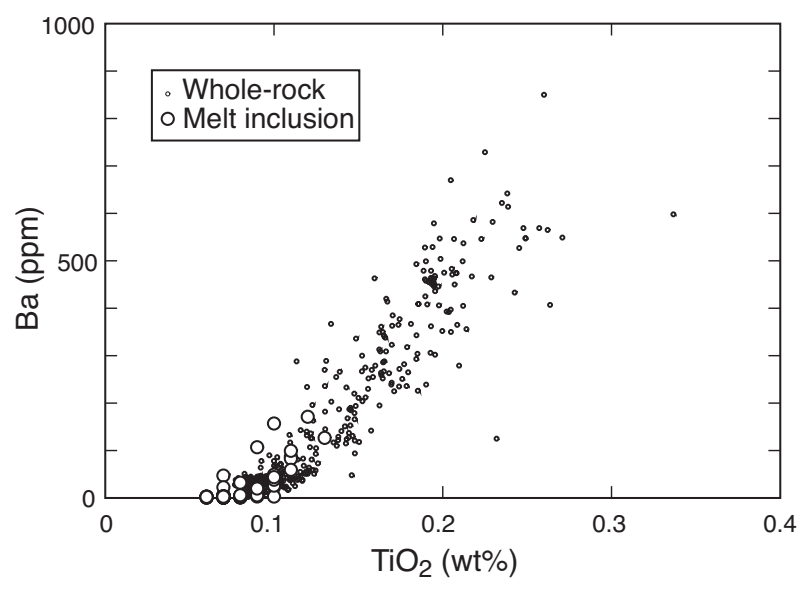

Figure 2. $\mathrm{Ba}(\mathrm{ppm}) \mathrm{vs}$. $\mathrm{TiO}_{2}(\mathrm{wt} \%)$ in Bishop Tuff pumice (wholerock) excluding 4 trachydacites and 2 dark pumices, from Hildreth and Wilson (2007, Appendix 4), and melt inclusions, from Wallace et al. (1999), Anderson et al. (2000), and Peppard et al. (2001). Note the similar trends but contrasting ranges in the two populations. Melt inclusion data are predominantly from CL-dark quartz interiors.

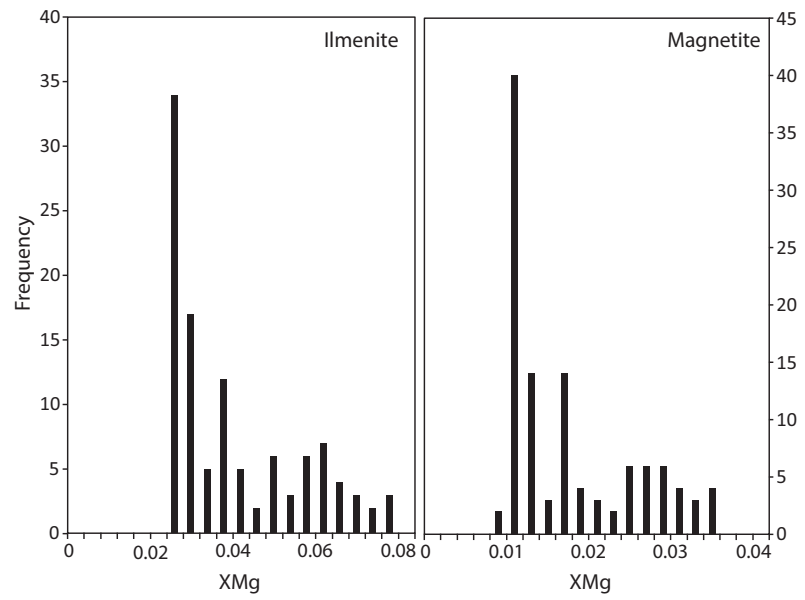

FIGURE 3. Frequency histograms for $X_{\mathrm{Mg}}\left[=\right.$ atomic $\left.\mathrm{Mg} /\left(\mathrm{Mg}+\mathrm{Fe}^{2+}\right)\right]$ in ilmenite and magnetite in the Bishop Tuff. Data from Hildreth (1977) and Hildreth and Wilson (2007, Appendix 3). This updates histograms in Gualda and Ghiorso (2013a) and Gardner at al. (2014). Data from sample BT129 were omitted because the ilmenite contains $14 \%$ pyrophanite component, anomalously little $\mathrm{Mg}\left(X_{\mathrm{Mg}}=0.01\right)$, and is clearly out of $\mathrm{MgFe}$-exchange equilibrium with its coexisting magnetite (Evans and Bachmann (2013). It was probably vapor-phase modified (Hildreth and Wilson 2007).

(Hildreth and Wilson 2007). These maxima reflect the fact that crystal-poor pumices of units Ig1 and F1-8 (Fig. 1) make up 2/3 or more of the eruptive volume accessible to sampling, and they are more easily sampled than pumices from the overlying Ig2 and $\mathrm{F} 9$ units. This effect shows up very clearly in the frequency histograms for whole-rock Ba and Sr (Fig. 4). Samples of late Bishop Tuff (as defined below) account for less than one-quarter of the accessible eruptive volume. Most of the compositional range in the main suite of pumice in the Bishop Tuff occurs in the Ig2 units.
TABLE 1. Comparison of the compositions of granite experimental charges with averages of early and late and pyroxenebearing the Bishop Tuff

\begin{tabular}{lrrrrc}
\hline $\mathrm{wt} \%$ & $\mathrm{AB421}$ & $\mathrm{LBT}$ & $\mathrm{PX}-\mathrm{LBT}$ & $\mathrm{AB} 401$ & \multicolumn{1}{c}{$\mathrm{EBT}$} \\
\hline $\mathrm{SiO}_{2}$ & 75.32 & 75.5 & 75.19 & 76.67 & 77.4 \\
$\mathrm{TiO}_{2}$ & 0.15 & 0.21 & 0.19 & 0.09 & 0.07 \\
$\mathrm{Al}_{2} \mathrm{O}_{3}$ & 12.71 & 13.0 & 13.36 & 12.10 & 12.3 \\
$\mathrm{FeO}$ & 1.62 & 1.1 & 1.23 & 0.92 & 0.7 \\
$\mathrm{MnO}$ & 0.06 & 0.03 & 0.03 & 0.02 & 0.04 \\
$\mathrm{MgO}$ & 0.23 & 0.25 & 0.27 & 0.05 & 0.01 \\
$\mathrm{CaO}$ & 0.90 & 0.95 & 0.94 & 0.53 & 0.45 \\
$\mathrm{Na}_{2} \mathrm{O}$ & 3.36 & 3.35 & 2.98 & 3.25 & 3.9 \\
$\mathrm{~K}_{2} \mathrm{O}$ & 4.61 & 5.55 & 5.33 & 5.12 & 4.8 \\
$\mathrm{P}_{2} \mathrm{O}_{5}$ & 0.05 & 0.06 & 0.07 & 0.01 & 0.01 \\
rest & 0.12 & & 3.00 & 0.09 & \\
Total & 99.13 & 100.00 & 99.60 & 98.85 & 99.78 \\
\hline
\end{tabular}

Notes: AB421, AB401: Klimm et al. (2008). LBT, EBT: Hildreth (1979), Hildreth and Wilson (2007). PX-LBT: average $(n=25)$ of pyroxene-bearing LBT, from Hildreth and Wilson (2007).

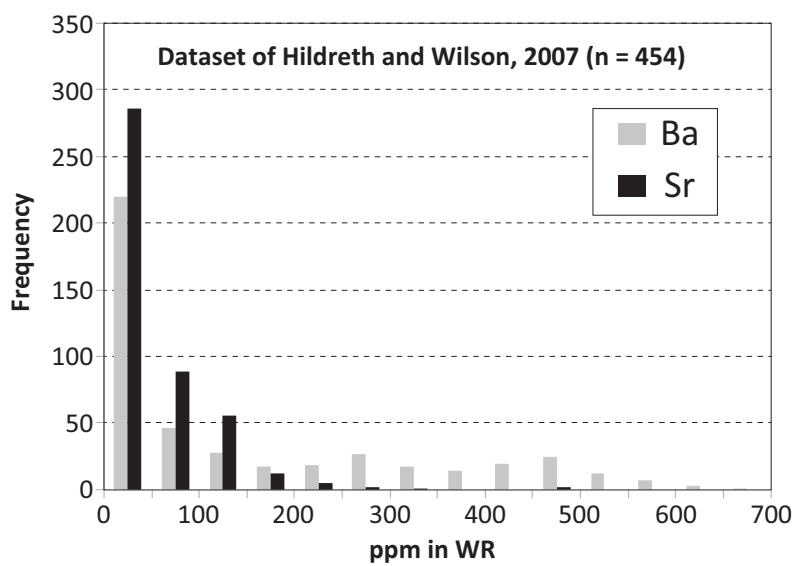

FIGURE 4. Frequency histogram for whole-rock $\mathrm{Ba}$ and $\mathrm{Sr}$ concentrations in main suite of the Bishop Tuff pumice. From data set of Hildreth and Wilson (2007, Appendix 4).

\section{Early and Late Bishop Tuff}

We believe that the most practical usage of the labels Early and Late Bishop Tuff (EBT and LBT) should refer to the absence in the former, and presence in the latter, of quartz with Ti-enriched rims, and sanidine margins enriched in $\mathrm{Ba}$ and $\mathrm{Sr}$. The presence of these "reverse" rim features, which are respectively bright in cathodoluminescence (CL) and electron backscatter (EBS) images, implies that LBT experienced a significant, late-magmatic event. Although pumice with bright-rimmed minerals is most commonly present in the temporally late sequence, that is, in Ig2 units (Fig. 1), these features can also be found in earlier erupted pumice; thus, a stratigraphic subdivision of EBT and LBT is less precise. Similarly, LBT pumice tends to be relatively crystal-rich, but crystal-rich pumice is in fact also present throughout the eruptive sequence (Fig. 1). Furthermore, it has become clear over the years that reversely zoned sanidine and quartz are largely found together with pyroxenes. These are recognized only among the "normal crystal-rich pumice" that increase greatly in abundance later in the eruptive sequence (Fig. 1). Averages of EBT and LBT pumice compositions (Table 1) show the former to be compositionally more evolved than the latter.

The bright rims of quartz and sanidine phenocrysts in LBT, 

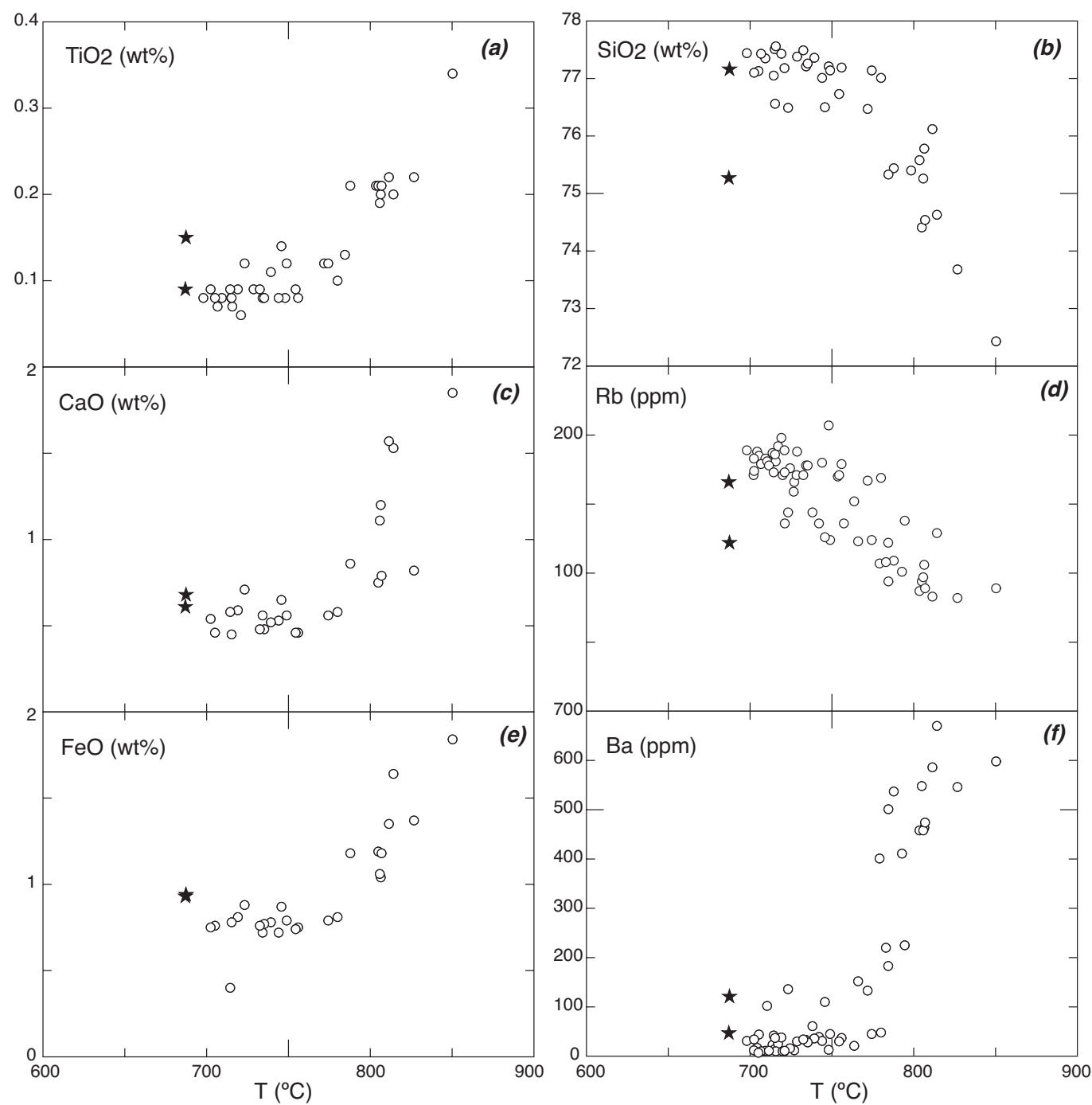

FIGURE 5. Correlation between FeTi-oxide temperature and whole-rock compositions for four compatible elements (a, c, e, f) and two incompatible elements $(\mathbf{b}, \mathbf{d})$ in the main array of the Bishop Tuff. Outlier samples B355B and B383B (stars) are inferred to have undergone post-depositional changes (Evans and Bachmann 2013). Seven duplicate oxide pairs were averaged. Data taken from Hildreth (1977) and Hildreth and Wilson (2007, Appendices 3 and 4) and Ghiorso and Evans (2008).

outboard of a resorption surface, are enriched $\mathrm{Ti}, \mathrm{Ba}, \mathrm{Sr}$, and LREE, and so, with $\mathrm{CO}_{2}$, are their melt inclusions (Hervig and Dunbar 1992; Wallace et al. 1999; Anderson et al. 2000; Peppard et al. 2001; Roberge et al. 2013). The margins of zircon crystals in LBT are similarly enriched in compatible elements and LREE and depleted in U and Th (Chamberlain et al. 2014b). These crystal rims grew by their envelopment in less evolved, hotter (Chamberlain et al. 2014a), and drier LBT magma (see below). The central "dark" parts of quartz and sanidine in samples of LBT have evolved chemical characteristics similar to EBT quartz and sanidine (low Ti and Ba, respectively, and similar melt-inclusion compositions), suggesting their derivation from the EBT magma. We can tell from their major and most trace element compositions that by far the preponderance of analyzed melt inclusions in quartz (91 out of 98; from Wallace et al. 1999; Anderson et al. 2000; Peppard et al. 2001) fall into this inherited "dark core" category
(Fig. 2). As discussed below, these observations are critical for the assessment of WR compositions and in attempts to use the compositions of melt inclusions for thermometry and barometry.

\section{THERMOBAROMETRY}

\section{Magnetite-ilmenite thermometry}

The continuity and covariation among observable properties of the Bishop Tuff, including the minerals, was already noted by Hildreth $(1977,1979)$. The compositions of the FeTi-oxide minerals, and the temperatures they indicated, figured prominently in this narrative. For example, Hildreth (1979) showed the existence of a correlation in the Bishop Tuff between the composition of plagioclase and the FeTi-oxide temperature, with the mean composition of plagioclase varying continuously from An14 in cool EBT to An23 in hotter LBT. Hildreth (1979) showed that compat- 
ible elements such as $\mathrm{Ca}, \mathrm{Ba}$, and $\mathrm{Eu}$ in sanidine, $\mathrm{Ba}, \mathrm{Ce}$ and $\mathrm{Eu}$ in plagioclase, and $\mathrm{Ti}, \mathrm{Ba}, \mathrm{V}$, and $\mathrm{Co}$ in biotite all decline with decrease in the FeTi-oxide temperature. Correlated, temperaturedependent changes in the compositions of apatite and zircon were also noted (Hildreth 1979). FeTi-oxide temperatures also correlated well with WR major- and trace-element compositions (Hildreth 1979). Notably, the oxide temperatures were shown by Hildreth (1979) to decline with increase in incompatible elements (Mn, Cs, Sc, Yb, Ta, U, Y, Rb) and with decrease in compatible elements (Mg, Fe, Ca, Ti, P, Ba, Ce, Eu, Zr, Sr).

Hildreth and Wilson (2007) supplied an expanded database of FeTi-oxide compositions and XRF whole-rock analyses for all units of the Bishop Tuff. The FeTi-oxide data were collected by microprobe from pairs of homogeneous grains in mutual contact (Hildreth and Wilson 2007). Use of the revised calibration of the ilmenite-magnetite thermometer of Ghiorso and Evans (2008) with this expanded database (Fig. 5) reinforces Hildreth's (1977, 1979) observations that higher concentrations of compatible elements $(\mathrm{Ca}, \mathrm{Ti}, \mathrm{Fe}, \mathrm{Ba})$ correspond to higher oxide temperatures, and conversely so for the incompatible elements (e.g., $\mathrm{Si}, \mathrm{Rb}$ ). FeTi-oxide temperatures appear to be accurate to about $\pm 30-40$ ${ }^{\circ} \mathrm{C}$ (e.g., Blundy and Cashman 2008), and analytically reproduceable to $5-10{ }^{\circ} \mathrm{C}$, provided that instances of inhomogeneity, oxyexsolution, and alteration are avoided. If the composition of ilmenite in the Late Bishop Tuff was largely arrived at syn- or post-eruptively (for example, Gualda and Ghiorso 2013a, 2013b; Gardner et al. 2014; see below), we fail to see how or why this event could restore/reproduce the relationships between the allegedly incorrect oxide temperatures and magma chemistry that are shown in Figure 5.

Given our definition of LBT (presence of reverse-zoned "bright rim" minerals) and especially the roles of high $\mathrm{Ba}$ and $\mathrm{Ti}$, samples of LBT are likely to have Fe-Ti oxide temperatures (Fig. 5) higher than $\sim 780{ }^{\circ} \mathrm{C}$ and whole-rock (WR) $\mathrm{SiO}_{2}<76 \mathrm{wt} \%$, total $\mathrm{FeO}>1.0 \mathrm{wt} \%, \mathrm{CaO}>0.75 \mathrm{wt} \%, \mathrm{TiO}_{2}>0.15 \mathrm{wt} \%$, and $\mathrm{Ba}$ $>300$ ppm. We note that the LBT sample population is limited; bright-rim material may make up only $\sim 10 \%$ of the (accessible) pumice, i.e., less than half the pumice in Ig2, which is itself only $20-33 \%$ of the whole accessible volume.

Concern about the validity of the FeTi-oxide temperatures in the Bishop Tuff surfaced when petrologic analysis of the ilmenitemagnetite-orthopyroxene-quartz assemblage gave widely varying and unrealistic results for pressure ( $<0$ to 5 kbar; Frost and Lindsley 1991, 1992; Ghiorso and Sack 1991; Lindsley et al. 1991). Much later, Evans and Bachmann (2013) illustrated the inherited nature of most of the pyroxenes in the Bishop Tuff with the aid of a Roozeboom diagram showing inconsistent $\mathrm{Fe} / \mathrm{Mg}$ exchange relations between the pyroxenes and FeTi-oxides. It seems, in retrospect, that the comparative homogeneity of the pyroxenes was the problem for which the evolving oxide minerals, specifically the ilmenite, received the blame.

A further apparent stumbling block was how to reconcile the roughly $100{ }^{\circ} \mathrm{C}$ thermal gradient inferred from the FeTi-oxides with the quartz-sanidine-plagioclase "eutectic" nature of the Bishop Tuff throughout (Ghiorso and Evans 2008, p. 1021). This question can be resolved (discussed under "Role of $\mathrm{CO}_{2}$ " below) when account is taken of the lower $\mathrm{H}_{2} \mathrm{O}$-activity of the LBT magma related to the presence of $\mathrm{CO}_{2}$ in the system and/or the partial remelting of dry cumulate crystals (Wolff et al. 2015). Finally, Ghiorso and Gualda (2013) argued that the positive slope of the Bishop Tuff oxides in a diagram of derived $\mathrm{aTiO}_{2}$ vs. $\mathrm{T}$ is thermodynamically problematic, and therefore the oxide pair were not to be considered in equilibrium. The pitfalls of this conclusion are also addressed below.

The irony of the condemnation of the FeTi-thermobarometer in the case of the Bishop Tuff is that the tightness of clustering of most of the datapoints in graphs of $X_{u s p}$ vs. $X_{i l m}$ and $\triangle N N O$ vs. $T^{\circ} \mathrm{C}$ is almost unsurpassed by comparable data from other well-studied volcanic centers (e.g., Ghiorso and Evans 2008). The consistency of $\mathrm{Mg} / \mathrm{Fe}$ partitioning in the Bishop Tuff among ilmenite, magnetite, and biotite (Evans and Bachmann 2013) is supported by the range $\left(570-900^{\circ} \mathrm{C}\right.$ ) in derived $\mathrm{MgFe}$-temperatures (Ghiorso and Evans 2008) that is not notably larger than several other volcanic centers. Fe/Ti exchange is in principle independent of
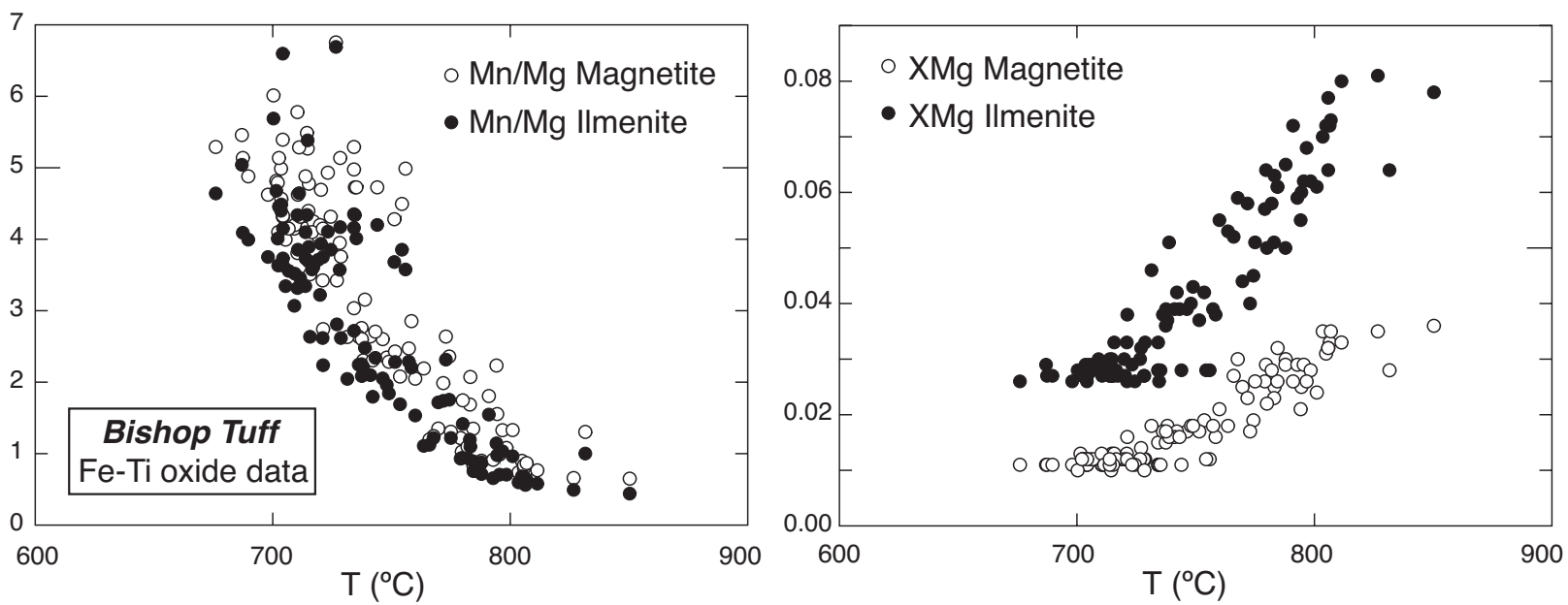

FIGURE 6. Weight ratio $\mathrm{Mn} / \mathrm{Mg}$ and atomic ratio $\mathrm{Mg} /\left(\mathrm{Mg}+\mathrm{Fe}^{2+}\right)$ of magnetite and ilmenite vs. FeTi-oxide temperature for all analyzed pairs in the Bishop Tuff. Data from Hildreth (1977), Hildreth and Wilson (2007), and Ghiorso and Evans (2008). 
$\mathrm{Fe} / \mathrm{Mg}$ exchange, and so taken together, despite their very different kinetics, these indications of exchange equilibria provide feeble support for a lack of chemical communication between the ilmenite and the magnetite in samples of LBT (cf. Gualda and Ghiorso 2013a).

Threefold changes in $X_{M g}$ in both magnetite and ilmenite (Evans and Bachmann 2013) match increases in the magma $X_{M g}$ from approximately 0.1 to 0.3 (Hildreth and Wilson 2007) in the main suite of white pumices from EBT to LBT (crystal-poor, crystal-medium, and crystal-rich). These compositional variations are produced by a magma differentiation process that is (largely?) driven by temperature change. Their mutual consistency when plotted against temperature (Fig. 6) suggests strongly that the FeTi-thermometer is accurately recording the process. Similarly, magnetite and ilmenite undergo nearly identical 10 -fold increases in $\mathrm{Mn} / \mathrm{Mg}$ ratio in response to magma evolution from $850{ }^{\circ} \mathrm{C}$ down to $700{ }^{\circ} \mathrm{C}$. The ratio $\mathrm{Mn} / \mathrm{Mg}$ in WR pumice also increases by an order of magnitude over the same range in temperature (although with $\mathrm{Mg}$ at the detection limit in evolved samples, the exact degree of change is hard to specify). Again, these internally consistent changes in mineral and pumice compositions as a function of FeTi-temperature are inconsistent with the view that the extracted temperatures are not to be trusted. We do acknowledge, however, that among the 111 analyzed ilmenite-magnetite pairs in the Bishop Tuff, we can identify a small number (3-5) that noticeably fail to conform to the smooth composition/temperature trends shown by the remainder (Figs. 6 and 7). In our view, these few analyses represent the extent to which the oxide minerals, notably the ilmenite, have been influenced by syn- or post-eruption processes.

Because $X_{u s p}$ of the magnetite is relatively constant at about 0.26 (Frost and Lindsley 1992; Ghiorso and Evans 2008), variation in the $\mathrm{TiO}_{2}$ content of ilmenite is recognized as driving the $f_{\mathrm{O}_{2}}-T$ trend in the Bishop Tuff oxides. Ghiorso and Gualda (2013) and Gualda and Ghiorso (2013a) maintain that this feature of the trend is a consequence of late- to post-magmatic alteration or formation of the modally small amounts of ilmenite, so that the compositions of the oxide pair do not accurately reflect magma chamber conditions. However, this interpretation of FeTiexchange disequilibrium is hard to reconcile with the evidence for the preservation of $\mathrm{Mg} / \mathrm{Fe}$ and $\mathrm{Mg} / \mathrm{Mn}$ exchange equilibrium among ilmenite, magnetite, and liquid magma discussed above.

Whereas the $\mathrm{Mg} / \mathrm{Fe}$ and $\mathrm{Fe}-\mathrm{Ti}$ exchange temperatures for the Bishop Tuff fall in the same range, we do not share the enthusiasm of Gardner et al. (2014) for the new and as yet minimally tested $\mathrm{Mg} / \mathrm{Fe}$-thermometer for ilmenite-magnetite pairs. By contrast, the experimentally calibrated and independently tested (Ghiorso and Evans 2008; Blundy and Cashman 2008) FeTi-thermometer is more reliable. As expected, $\mathrm{Mg} / \mathrm{Fe}$ exchange between magnetite and ilmenite proves to be less sensitive to temperature than the Fe-Ti thermometer, and they correlate poorly (slope $m=0.62, \mathrm{R}^{2}$ $=0.185$ ). The poor correlation between $\mathrm{Mg} / \mathrm{Fe}$ and $\mathrm{Fe}$-Ti exchange temperatures can be attributed to the larger uncertainties in the $\mathrm{Mg} / \mathrm{Fe}$ thermometer (as noted at http://ctserver.ofm-research. org/), the sources of which are analytical and theoretical. Concentrations of $\mathrm{MgO}$ in the oxides in Bishop Tuff pumice are small: in ilmenite $0.59-1.8 \mathrm{wt} \%$ and in magnetite $0.22-0.80 \mathrm{wt} \%$. Also, it is necessary to partition $\mathrm{Fe}^{2+}$ and $\mathrm{Fe}^{3+}$ from total $\mathrm{Fe}$ based on spinel and rhombohedral-oxide formula proportions. MgFe-partitioning between ilmenite and magnetite is not pronounced (Fig. 6), whereas the partitioning of $\mathrm{Fe}^{2+} \mathrm{Ti}\left(\mathrm{Fe}^{3+}\right)_{-2}$ is strong: $600-800$ ${ }^{\circ} \mathrm{C}$ isotherms are close to the $\mathrm{x}$ - and $\mathrm{y}$-axes of the Roozeboom plot (Ghiorso and Evans 2008). Accordingly, the standard Gibbs energy and enthalpy of Fe-Ti exchange are predictably larger than those for $\mathrm{Mg} / \mathrm{Fe}$ exchange, so the former thermometer has a stronger dependence of the equilibrium constant $\operatorname{lnKex}$ on inverse temperature. A quantitative thermodynamic analysis of $\mathrm{Fe}^{2+}-\mathrm{Mg}$ exchange between ilmenite and magnetite in the Bishop Tuff was published as Figure 25 in Ghiorso and Evans (2008). As for $\mathrm{Fe} / \mathrm{Mg}$, the partition of $\mathrm{Mn}$ and $\mathrm{Mg}$ between magnetite and ilmenite is not useful as a geothermometer. Figure 6 shows that the partitioning is small. The raw $\mathrm{Kd}$ or $\operatorname{lnKd}$ for $\mathrm{Mn} / \mathrm{Mg}$ exchange correlate poorly $\left(\mathrm{R}^{2}=0.185\right.$ and 0.153 respectively) with the FeTi-exchange thermometer.

Gardner et al. (2014) criticized our use of Roozeboom and Nernst diagrams to examine exchange equilibrium among coexisting minerals (Evans and Bachmann 2013). We defend their use while freely admitting that they only test exchange equilibrium and do not prove it quantitatively, namely that: "the chemical potential difference of the exchange reaction... is zero over the inferred temperature range of interest" (Gardner et al. 2014, p. 13). Conversely, the diagrams reliably show instances of disequilibrium, as we have noted for the pyroxenes (Evans and Bachmann 2013).

Support of a different kind for the validity of the Fe-Ti oxide temperature estimates in the Bishop Tuff was provided by Anderson et al. (2000): "Some pyroxene-bearing LBT samples contain two populations of titaniferous magnetite (both with Xusp $=0.26$ ), low-Mg titaniferous magnetite as inclusions in quartz and higher-Mg titaniferous magnetite as individual grains within (matrix) glass. The latter approach Fe-Mg exchange equilibrium with the pyroxenes." These statements are consistent with low$\mathrm{Mg}$, evolved magnetite inside EBT (antecryst) quartz, and later

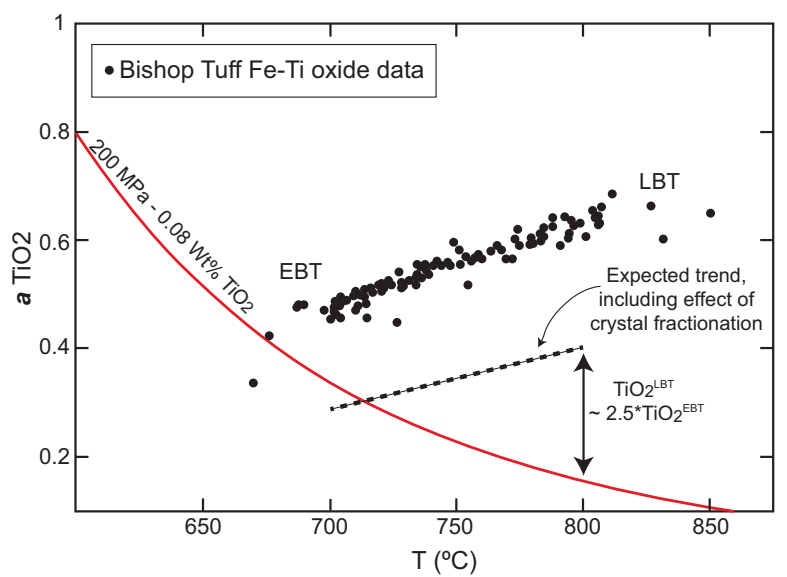

Figure 7. Curve of $a \mathrm{TiO}_{2}$ vs. $\mathrm{T}$ at $200 \mathrm{MPa}$ for a Bishop Tuff composition with $0.08 \mathrm{wt} \% \mathrm{TiO}_{2}$ and corresponding loci of the $\mathrm{Fe}-\mathrm{Ti}$ oxides (dots), from Ghiorso and Gualda (2013) with permission of Springer, compared to the expected change in $a \mathrm{TiO}_{2}$ vs. $T$ (dashed line) assuming a difference of $\mathrm{X} 2.5$ in melt $\mathrm{TiO}_{2}$ between EBT at $700{ }^{\circ} \mathrm{C}$ and LBT at $800{ }^{\circ} \mathrm{C}$ (see text for details). 
growth of high-Mg magnetite from less evolved LBT matrix liquid following a recharge event.

\section{$\mathrm{TiO}_{2}$ activity}

Ghiorso and Gualda (2013) showed that the solubility of rutile in magmatic liquids declines, as expected, with decreasing temperature, so that the slope of a graph of the activity of $\mathrm{TiO}_{2}$ vs. $T^{\circ} \mathrm{C}$ based on the compositions of coexisting ilmenite and magnetite in a magma whose composition does not vary appreciably should ordinarily have a negative slope. This assumption seemed reasonable in light of $\mathrm{TiO}_{2}$ values of 0.08 and $0.09 \mathrm{wt} \%$ adopted for EBT and LBT liquids respectively, based on the average compositions of melt inclusions (MI) in quartz phenocrysts (Anderson et al. 2000). However, as discussed above, we strongly suspect that the MI used by Ghiorso and Gualda (2013) largely represent highly evolved EBT compositions, not the extremes of liquid composition corresponding to the analyzed FeTi-oxide minerals in the Bishop Tuff. We present here (Fig. 7) a revised version of Figure 4 in Ghiorso and Gualda (2013) based on what we feel are more likely liquid compositions matching the 700 and $800{ }^{\circ} \mathrm{C}$ oxide temperatures.

Measured Ti contents of MI in cores and rims of LBT quartz (Fig. 2) were found to range from 353 to $786 \mathrm{ppm}\left(\mathrm{TiO}_{2}\right.$ from 0.06 to $0.13 \mathrm{wt} \%$ ) by Wallace et al. (1999), Anderson et al. (2000), and Peppard et al. (2001). Elements in MI trapped in bright overgrowths were shown to be less evolved than MI in dark interiors (Peppard et al. 2001; Roberge et al. 2013). Chamberlain et al. (2015) analyzed matrix glasses in main-suite Bishop Tuff pumice and found $\mathrm{Ti}$ contents ranging from less than 400 to as much as $970 \mathrm{ppm}$ when averaged according to stratigraphic unit. In relative proportions, this range is not unlike that found for $\mathrm{Ti}$ in Bishop Tuff quartz by Wark et al. (2007). The overall range of Ti analyses in main-suite matrix-glass samples reported by Chamberlain et al. (2015) is larger, namely from 310 to 1280 ppm $\left(0.05\right.$ to $\left.0.21 \mathrm{wt} \% \mathrm{TiO}_{2}\right)$; five samples of EBT averaged 407-416 ppm Ti (0.07 wt $\left.\% \mathrm{TiO}_{2}\right)$. Whole-rock (WR) $\mathrm{TiO}_{2}$ in the FeTi-thermometer population ranges from 0.07 to $0.22 \mathrm{wt} \%$, a threefold change (Fig. 5); the WR values for LBT are likely to be as much as $0.045 \mathrm{wt} \% \mathrm{TiO}_{2}$ larger than matrix glass owing to the presence of $\sim 0.5 \%$ magnetite (Hildreth and Wilson 2007). In light of the above, rather than $0.09 \mathrm{wt} \% \mathrm{TiO}_{2}$, we prefer to select

TABLE 2. Estimate of the bulk partition coefficient for Ti in the Bishop Tuff magma

\begin{tabular}{lccc}
\hline Mineral & Mode & $\begin{array}{c}\text { D value } C_{\mathrm{Ti}} \\
\text { in melt }=0.1 \mathrm{wt} \%\end{array}$ & $\begin{array}{c}\text { D value } \mathrm{C}_{\mathrm{Ti}} \\
\text { in melt }=0.2 \mathrm{wt} \%\end{array}$ \\
\hline Quartz & 0.42 & 0.1 & 0.1 \\
Plagioclase & 0.18 & 0.1 & 0.1 \\
Sanidine & 0.34 & 0.1 & 0.1 \\
Biotite & 0.03 & 50 & 25 \\
Pyroxene & 0.01 & 0.5 & 0.5 \\
Ilmenite & 0.0005 & 490 & 245 \\
Magnetite & 0.02 & 90 & 45 \\
& Bulk D & $\sim 3.6$ & $\sim 1.9$ \\
\hline
\end{tabular}

Notes: Mineral modes from Hildreth 1977, Appendix XII. Partition coefficients ( $D$ value) of plagioclase and clinopyroxene were taken from GERM database (http://earthref.org/KDD/). D values for sanidine and quartz were estimated to be similar to plagioclase. D values of biotite, ilmenite, and magnetite were estimated using an average Ti concentration in the minerals from Hildreth (1977; $5 \mathrm{wt} \% \mathrm{TiO}_{2}$ in the biotite, $49 \mathrm{wt} \% \mathrm{TiO}_{2}$ in ilmenite, $9 \mathrm{wt} \% \mathrm{TiO}_{2}$ in the magnetite, and $\sim 0.1$ or $0.2 \mathrm{wt} \% \mathrm{TiO}_{2}$ in the melt).

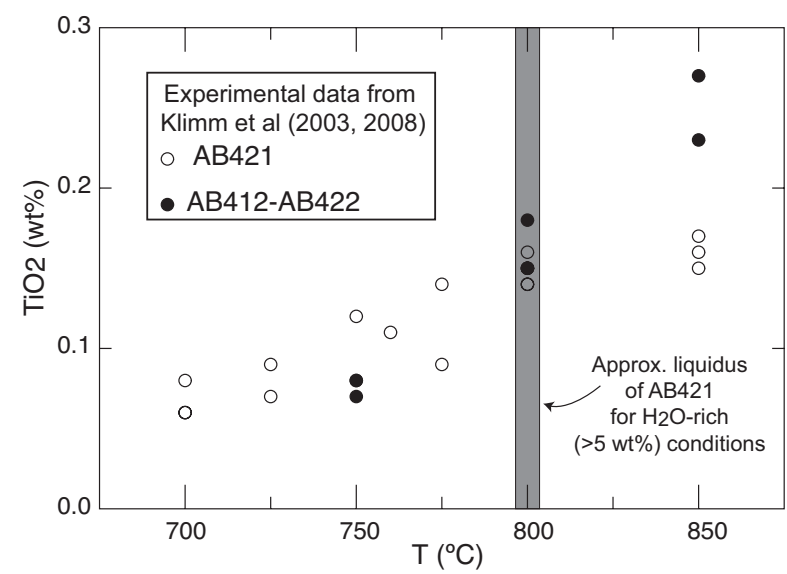

FIGURE 8. $\mathrm{TiO}_{2}$ content vs. $T$ for high-silica matrix melts saturated in FeTi oxides in high-temperature experiments on three fused granitoids (Klimm et al. 2003, 2008), showing the igneous compatibility of $\mathrm{TiO}_{2}$ at $\Delta \mathrm{NNO}=0$ to $-1.0\left(\right.$ decrease of $\mathrm{TiO}_{2}$ as a function of $\left.T\right)$.

a more likely $0.18 \mathrm{wt} \%$ for the LBT matrix liquid matching the $800{ }^{\circ} \mathrm{C}$ oxide temperature; and rather than $0.08 \mathrm{wt} \% \mathrm{TiO}_{2}$, we believe a figure of $0.07 \mathrm{wt} \%$ best represents EBT matrix liquid corresponding to the lowest $\left(700^{\circ} \mathrm{C}\right)$ temperature. If, accordingly, we adjust the MELTS-derived curve of $a T_{i} O_{2}$ vs. $T^{\circ} \mathrm{C}$ for Bishop Tuff rhyolite in Ghiorso and Gualda (2013, their Fig. 4) to fit these preferred estimates of liquid composition (a conservative enrichment factor of $0.18 / 0.07 \sim 2.5$ between the EBT and LBT), we recover a line with a low-angle positive slope (Fig. 7). Our adjustment assumes Henry's Law behavior of $\mathrm{TiO}_{2}$ in the liquid. Why our adjusted line is 0.2 units of $a \mathrm{TiO}_{2}$ lower than the measured FeTi-oxide data set for the Bishop Tuff is unclear, but we suspect it is a thermodynamic rather than disequilibrium problem.

A comparison of Figures 1 and 2 in Ghiorso and Gualda (2013, $\triangle N N O$ vs. $T^{\circ} \mathrm{C}$ and $a T_{i} O_{2}$ vs. $T^{\circ} \mathrm{C}$, respectively) shows that negative-sloped trends of $a \mathrm{TiO}_{2}$ vs. $\mathrm{T}^{\circ} \mathrm{C}$ data-points in their Figure 2 are a property of relatively oxidized intermediate to silicic magmas $(\triangle N N O>1)$, whereas positive-sloped data points correspond to reduced magmas $(\triangle N N O<1)$. FeTi-oxide minerals in the reduced magmas are Ti-rich (Ghiorso and Evans 2008; namely $X_{u s p}=0.2-0.6$ and $\left.X_{i l m}=0.75-0.93\right)$, whereas in more oxidized magmas, they are Ti-poor: $X_{u s p}<0.2$ and $X_{i l m}<0.7$, so the compatibility differences for Ti in these magmas are somewhat predictable. We calculate here (Table 2) a partition coefficient $\mathrm{D}_{\mathrm{Ti}}$ of 2-3.5 for the Bishop Tuff magma with modal proportions given in Hildreth (1977, Appendix XII). These calculations of $\mathrm{D}_{\mathrm{Ti}}$ are obviously rough because the modal proportions of magnetite and ilmenite are nearly impossible to measure separately, but the results are borne out by the measured temperature dependence of whole-rock $\mathrm{TiO}_{2}$ (Fig. 5), the $\mathrm{TiO}_{2}$ vs. $\mathrm{SiO}_{2}$ variation diagram (Hildreth and Wilson 2007, their Fig. 9), and the calculated Ti enrichment factor of $\approx 74 \%$ (Hildreth 1979; Wolff et al. 2015). Thus, fractional crystallization of the FeTi-oxides can be expected to deplete $\mathrm{Ti}$ in the residual liquid of reduced magmas such as the Bishop Tuff, with somewhat less Ti-depletion in the residual liquid in the case of more oxidized magmas such as the Pinatubo and Shiveluch lavas. 
Such behavior was experimentally confirmed at $f_{\mathrm{O}_{2}}$ of $\triangle \mathrm{NNO}$ $=0$ to $-1.0 \log$ units by Klimm et al. $(2003,2008)$, using rhyolitic compositions with $0.55,0.38$, and 0.17 bulk $\mathrm{TiO}_{2}$ contents (wt $\%$ ), thus comparable to the full spectrum of Bishop Tuff pumice. For a relatively evolved composition such as AB421 (Table 1), FeTioxide saturated residual liquids have $\mathrm{TiO}_{2}$ contents of about 0.15 wt $\%$ at $800{ }^{\circ} \mathrm{C}$, whereas at $700{ }^{\circ} \mathrm{C}, \mathrm{TiO}_{2}$ has fallen to $0.06 \mathrm{wt} \%$ (Fig. 8). This covariation of temperature and melt $\mathrm{TiO}_{2}$ content is identical to that displayed by the Bishop Tuff. The flattened trend of AB421 above $800{ }^{\circ} \mathrm{C}$ in Figure 8 reflects the fact that this magma is above its liquidus.

The contrasting positive and negative slopes for $a T_{i} O_{2}$ vs. $T$ ${ }^{\circ} \mathrm{C}$ are thus a reflection of magmatic differentiation trends that differ in their igneous compatibility of Ti. In the Bishop Tuff, crystal-liquid fractionation produced the highly evolved, crystalpoor EBT pumice (Hildreth and Wilson 2007), but magma mixing and cumulate melting at deeper levels likely contributed to the overall compositional diversity as well (see Implications section). In our view, Ghiorso and Gualda (2013) (and Thomas and Watson 2012) underestimate the influence of magmatic differentiation on the trend of variation of $\mathrm{TiO}_{2}$-activity with temperature. We also note that biotite in the Bishop Tuff shows a positive correlation between its $\mathrm{TiO}_{2}$ content and the FeTi-oxide temperature (Hildreth 1979). This calls for a basic exchange-equilibrium control of the compositions of both biotite and ilmenite.

The $T-f_{\mathrm{O}_{2}}$ trends for the Bishop Tuff and the similarly reduced Taupo oxides fall very close to one another (Ghiorso and Gualda 2013). Rhyolites from the Oruanui eruption, Taupo Volcano, New Zealand, show about the same relative decline in wholerock $\mathrm{wt} \% \mathrm{TiO}_{2}$ as the Bishop Tuff, from 0.42 to 0.16 , as $\mathrm{SiO}_{2}$ (anhydrous) increases from 76 to $79 \mathrm{wt} \%$ (Wilson et al. 2006). The positive slope of $a \mathrm{TiO}_{2}$ vs. $T$ for such reduced magmas is not a "thermodynamic inconsistency" (Gualda and Ghiorso 2013a). It is a petrologic requirement of magmatic differentiation in reduced magmas wherein the cooling trend is away rather than towards rutile saturation, that is, a "compositional" as much as a "thermodynamic" control. If the Bishop Tuff oxides are out of equilibrium, then so are the Taupo and the Yellowstone oxides (Ghiorso and Gualda 2013), which pass the $\mathrm{Mn} / \mathrm{Mg}$ partition test (Bacon and Hirschmann 1988). Oxide temperatures extracted from cummingtonite-bearing Taupo rhyolites were shown (Ghiorso and Evans 2008, Fig. 28) to be in agreement with those from other cummingtonite-bearing volcanics and the amphibole quadrilateral phase diagram. It is thus inappropriate in our opinion to condemn the veracity of the FeTi-oxide thermobarometer for the Bishop Tuff (or any other reduced metaluminous magma) on the basis of a positive slope for $a \mathrm{TiO}_{2}$ vs. $T$.

\section{Other thermometers}

Other thermometers applied to the Bishop Tuff deposits are discussed below. Notwithstanding their different kinetics, they all agree with the ilmenite-magnetite thermometer in showing that EBT and LBT magmas record respectively low and high temperature, and thus the Bishop Tuff magma reservoir was thermally zoned prior to its eruption:

1. The $\Delta^{18} \mathrm{O}$ quartz-magnetite thermometer applied to EBT and LBT pairs gave a temperature range of 715 to 815 ${ }^{\circ} \mathrm{C}$ (Bindeman and Valley 2002). This range is remark- ably close to that indicated by FeTi-oxide thermometry (Figs. 5, 6, and 7).

2. A temperature difference of $\sim 80^{\circ} \mathrm{C}\left(740-820^{\circ} \mathrm{C}\right)$ between the earlier- and later-erupted regions of the magma chamber was determined by Chamberlain et al. (2014a) for host-and-inclusion pairs of sanidine and plagioclase. All inclusions measured were within the BSE-dark cores of sanidine crystals, so this range in temperature may be a minimal one for the entire suite according to our definition of LBT. Their two-feldspar temperatures show a positive correlation with $\mathrm{Fe}$ - $\mathrm{Ti}$ oxide temperatures (their Fig. 2).

3. Ti in quartz thermometry (TitaniQ) showed a range from $\sim 720$ to $820^{\circ} \mathrm{C}$ on the assumption of a constant activity of 0.6 for $\mathrm{TiO}_{2}$ in the liquid (Wark et al. 2007). Whereas the experimental calibration used by Wark et al. (2007) has been supported by more recent work (Thomas et al. 2015), there remains the need to recognize that $a\left(\mathrm{TiO}_{2}\right)$ varies with temperature and liquid composition (Ghiorso and Gualda 2013). $\mathrm{TiO}_{2}$ activity can in principle be determined from the $\mathrm{TiO}_{2}$ contents of nearby melt inclusions and from the compositions of FeTi-oxide in the same sample (assuming they are in frozen equilibrium). This problem is a practical matter that future work may well resolve.

4. Gualda and Ghiorso (2013a) found that average zirconsaturation temperatures $\left(735 \pm 16\right.$ and $\left.735 \pm 23^{\circ} \mathrm{C}\right)$ were identical in EBT and LBT pumices. These results were based on the $\mathrm{Zr}$ contents of glass inclusions in quartz using analytical data from Wallace et al. (1999), Anderson et al. (2000), and Peppard et al. (2001), and the experimental calibration of Watson and Harrison (1983). Only seven of the 97 spots in the analyzed population have more than $80 \mathrm{ppm} \mathrm{Ba}$. Hence it appears that at least $90 \%$ of the analyses represent EBT and that they are from melt inclusions inside the "dark" interiors of quartz. $735^{\circ} \mathrm{C}$ is not significantly different from the average temperature $\left(728 \pm 19{ }^{\circ} \mathrm{C}\right.$ s.d.) given by the oxide thermometer of Ghiorso and Evans (2008) for $42 \mathrm{EBT}$ pumices identified by their low contents of Ba and Ti (Fig. 2). Gualda and Ghiorso (2013a) mentioned that melt in quartz rims is somewhat enriched in $\mathrm{Zr}$ relative to melt in crystal interiors, citing one result ( $120 \mathrm{ppm} \mathrm{Zr}$ ) from Peppard et al. (2001) that is equivalent to $765^{\circ} \mathrm{C}$. However, Gualda and Ghiorso (2013a, p. 762) are dismissive of quartz-rim MI because " ...these inclusions were trapped during decompression shortly before eruption (they were syn-eruptive) and are thus not representative of pre-eruption storage conditions." For the many reasons discussed in this paper, we disagree with this interpretation of inclusions in quartz rims, and conclude instead that the temperatures derived by Gualda and Ghiorso (2013a) for interior melt inclusions in samples of LBT largely represent the same event, namely the pre-recharge crystallization of quartz in EBT. Peppard et al. (2001) interpreted their inclusion data as showing that "The near-rim, late erupted (entrapped) inclusions have greater $\mathrm{Zr}$ (despite nearly similar $\mathrm{SiO}_{2}$ $\mathrm{wt} \%$, see below), suggesting a higher temperature of 
entrapment coeval with crystallization of CL bright-rim zones." The average $\mathrm{Zr}$-content of the seven high-Ba spots is $114 \mathrm{ppm}$, which would correspond to about 758 ${ }^{\circ} \mathrm{C}$, and so it seems likely that none of the analyzed MI truly represent LBT. Maximum Zr concentrations of 140 to $170 \mathrm{ppm}$ were measured in Ba-enriched matrix glass of pumices from Ig2 packages by Chamberlain et al. (2015), signifying temperatures in the range 775 to 792 ${ }^{\circ} \mathrm{C}$. We note here also that Bindeman and Valley (2002) obtained zircon-saturation temperatures of $760-800{ }^{\circ} \mathrm{C}$ for the LBT and $730-735^{\circ} \mathrm{C}$ for the EBT (by measuring bulk rock data, the mass of zircon crystallized, and the rock's crystal content), consistent with FeTi-oxide and oxygen-isotope temperatures. A new calibration of zircon-saturation (Boehnke et al. 2013) suggests that the above zircon-saturation temperatures should be lowered by $45-55^{\circ} \mathrm{C}$ for the Bishop Tuff $\mathrm{Zr}$ concentrations. We conclude at this time that the zircon saturation temperatures for LBT are higher than for EBT, but that the exact temperature values (down to $675^{\circ} \mathrm{C}$ for $80 \mathrm{ppm} \mathrm{Zr}$ in EBT) may now be slightly too low.

\section{Melt inclusions and reverse-zoned rims}

Elevated amounts of compatible trace elements such as Ti, Ba, $\mathrm{Sr}$, and LREE, and low concentrations of incompatible elements such as Rb and HREE that are comparable to LBT whole-rock values were found only in a very small proportion of quartz melt inclusions in LBT samples, and none in Early and Middle BT samples (Wallace et al. 1999; Anderson et al. 2000). Melt inclusions in actual CL-bright rims of quartz are evidently poorly represented in the analyzed population (Peppard et al. 2001). This may in part be attributed to the fact that most MI in the bright rims are devitrified, and the main goal of these studies was the volatiles rather than their content of $\mathrm{Ti}, \mathrm{Ba}$, and $\mathrm{Zr}$, etc. Wallace et al. (1999) and Anderson et al. (2000) found the highest $\mathrm{CO}_{2}$ contents of all (300 to more than $1000 \mathrm{ppm}$ ) in the MI in quartz rims of LBT pumices, leading there to the highest gas saturation pressures (Wallace et al. 1999). With additional measurements, Roberge et al. (2013) suggested 150-200 MPa for early melt inclusions and 200-280 MPa for rim inclusions.

Many studies in the last two or three decades have raised legitimate questions regarding how well the measured compositions of $\mathrm{MI}$ in magmatic minerals faithfully retain the initial composition of the trapped liquid (e.g., Baker 2008). In the Bishop Tuff the more immediate question is whether, in their entirety, MI in samples labelled EBT and LBT on stratigraphic grounds truly represent liquid trapped from those different magmas, as assumed by Gualda et al. (2012a) and Gualda and Ghiorso (2013a, 2013b). Melt inclusions in LBT quartz, mostly in their dark interiors, are highly evolved compositionally, very similar to EBT inclusions, and very different from the average LBT composition (Gualda et al. 2012a). Some are also partly faceted (Gualda et al. 2012b), probably a result of reheating, with the potential for gain or loss of volatile constituents such as $\mathrm{H}$ and $\mathrm{Li}$. In our opinion, extensive and intensive parameters for the LBT event in the Bishop Tuff can only safely be derived from melt inclusions clearly identified as occurring in the "bright rims." Unfortunately, it seems that this is a very challenging task.
A key question is how fast these rims grew. Estimates range from a few days (syn-eruptive growth, Gualda and Ghiorso, 2013a) to several centuries (Chamberlain et al. 2014a). Some bright rims on quartz can measure up to $300 \mu \mathrm{m}$ across (e.g. Wark et al. 2007), representing 20-30\% of the crystal radii, and corresponding to $60 \mathrm{vol} \%$ of the crystals (Peppard et al. 2001). Thus, following an initial dissolution step, there was in fact a considerable increment of crystallization during the LBT event. Whereas rim growth during eruption would proceed without needing nucleation, it would require very fast diffusion rates in the liquid surrounding the crystals to feed such large rims. Based on modelling of Ti-in-quartz diffusion timescales, Chamberlain et al. (2014a, and personal communication) found that "at 760 ${ }^{\circ} \mathrm{C}$, only 11 out of 151 profiles" would be consistent with less than 10 years of diffusion following the LBT event. Profiles for $\mathrm{Ba}$ and $\mathrm{Sr}$ in feldspar and $\mathrm{Mg} / \mathrm{Fe}$ in pyroxene suggested longer timescales as well (Chamberlain et al. 2014a). The above observations indicate that decompression-induced dissolution and growth during eruption is an unlikely explanation for the CL-bright rims on LBT quartz.

Pamukcu et al. (2012) used the pattern of crystal-size distributions in LBT quartz and feldspar to show that the finegrained population $(<100 \mu \mathrm{m})$ crystallized under conditions of supersaturation during decompression. This population does not include "bright" overgrowths on pre-existing quartz and sanidine phenocrysts. Elsewhere, granophyric textures have been shown to develop by rapid growth following decompression in silicic ignimbrites (e.g. Lipman et al. 1997; Lowenstern et al. 1997). These microlitic and granophyric textures are logical candidates for the products of rapid, syn-eruptive, decompression-driven crystallization, not the reversely-zoned rims that are seen on the Bishop Tuff phenocrysts that significantly differ from EBT in their geochemistry. The "bright-rim" event involved partial melting (clear resorption features, see for example Peppard et al. 2001) followed by renewed crystallization of quartz and sanidine, a scenario more complex than decompression-driven crystallization. As stated by Anderson et al. (2000, p. 460), “... both quartz and sanidine phenocrysts from the late-erupted Bishop Tuff evidently grew from liquids that were increasingly $\mathrm{Ba}$ and $\mathrm{CO}_{2}$ rich.”

\section{Role of $\mathrm{CO}_{2}$ : Elevated LBT temperatures}

Wallace et al. (1995, 1999), Anderson et al. (2000), and Roberge et al. (2013) found 500-1000 ppm of $\mathrm{CO}_{2}$ in LBT glass rim inclusions, in contrast to 6-300 ppm in $\mathrm{MI}$ in early and middleerupted pumices (see also summary plot in Ghiorso and Gualda 2015). Their calculated values for $X_{\mathrm{H}_{2} \mathrm{O}}$ of the attendant fluid compare well with 0.59 obtained from VolatileCalc (Newman and Lowenstern 2002) for LBT liquid at $820{ }^{\circ} \mathrm{C}$ with $4 \mathrm{wt} \% \mathrm{H}_{2} \mathrm{O}$ and 600 ppm $\mathrm{CO}_{2}$ (Evans and Bachmann 2013). Phase-equilibrium experiments on $\mathrm{H}_{2} \mathrm{O}-\mathrm{CO}_{2}$-bearing magmas (including Holloway and Burnham 1972; Rutherford et al. 1985) have shown that at fixed pressure and temperature, increasing proportions of $\mathrm{CO}_{2}$ in the fluid invariably increase magma crystallinity and sometimes change phase assemblages. Although weakly soluble in lowpressure silicate melts, the addition of $\mathrm{CO}_{2}$ to the fluid greatly diminishes the $\mathrm{H}_{2} \mathrm{O}$-activity of the coexisting melt (Holloway 1976).

Data on the solubility of $\mathrm{H}_{2} \mathrm{O}$ and $\mathrm{CO}_{2}$ in rhyolitic melts (Silver et al. 1990; Blank et al. 1993; Zhang 1999; Tamic et al. 2001) 
may be used to extract values for the fugacity of $\mathrm{CO}_{2}$ and $\mathrm{H}_{2} \mathrm{O}$. This enables $\mathrm{CO}_{2}$ to be expressed as a function of temperature at fixed total pressure in terms of the mole fraction of $\mathrm{CO}_{2}$ in a mixed $\mathrm{H}_{2} \mathrm{O}-\mathrm{CO}_{2}$ fluid and $\mathrm{wt} \% \mathrm{H}_{2} \mathrm{O}$ in the melt (for example, Scaillet and Evans 1999, Table 2, their Fig. 12). Experimental solubility data show that the relationships between $f_{\mathrm{CO}_{2}}$ and $\mathrm{CO}_{2 \text { melt }}(\mathrm{ppm})$ can be faithfully expressed as (see for instance Blank et al. 1993; Lesne et al. 2011):

$$
f_{\mathrm{CO}_{2}}=a_{\mathrm{CO}_{2} \text { (melt) }}^{\mathrm{b}}
$$

where $\mathrm{a}$ and $\mathrm{b}$ are empirically fitted parameters specific to melt composition (see Fig. 2 in Blank et al. 1993). By virtue of thermodynamic equilibrium between fluid and melt, the relationships between $f_{\mathrm{CO}_{2}}$ and the mole fraction of $\mathrm{CO}_{2}$ in the coexisting fluid $\left(X_{\mathrm{CO}_{2}}\right)$ are then given by the standard equation:

$$
f_{\mathrm{CO}_{2}}=X_{\mathrm{CO}_{2}} \gamma \mathrm{CO}_{2} \cdot P_{\text {tot }}
$$

where $\gamma \mathrm{CO}_{2}$ is the fugacity coefficient of $\mathrm{CO}_{2}$ at the pressure and temperature of interest, and $P_{\text {tot }}$ is the total pressure. The fugacity coefficient is determined using an equation of state, in the present case the Modified Redlick-Kwong one (MRK, Holloway 1987). For the sake of simplicity, we make the assumption that the fluid follows the Lewis and Randall rule (ideal mixing of real fluids), which is equivalent to saying that departure from ideality of any fluid species $\left(\mathrm{H}_{2} \mathrm{O}\right.$ and $\left.\mathrm{CO}_{2}\right)$ is not affected by mixing, which is a good first approximation (see Ferry and Baumgartner 1987). Further assuming that the fluid is made primarily of $\mathrm{H}_{2} \mathrm{O}$ and $\mathrm{CO}_{2}$ allows one to find the corresponding $X_{\mathrm{H}_{2} \mathrm{O}}\left(=1-X_{\mathrm{CO}_{2}}\right)$. We have used this procedure (Fig. 9) for two granite compositions closely resembling EBT and LBT (Klimm et al. 2008), whose phase diagrams are shown with added isopleths for $\mathrm{CO}_{2}$ in the melt. At a pressure of $200 \mathrm{MPa}$, the presence of $600 \mathrm{ppm} \mathrm{CO}$ in the melt and $X_{\mathrm{H}_{2} \mathrm{O}} \sim 0.6$ in the fluid elevates the solidus by about $75^{\circ} \mathrm{C}$ (from 665 to $740{ }^{\circ} \mathrm{C}$ ), and the quartz-liquidus by about 90 ${ }^{\circ} \mathrm{C}$ (from 675 to $765^{\circ} \mathrm{C}$ ).
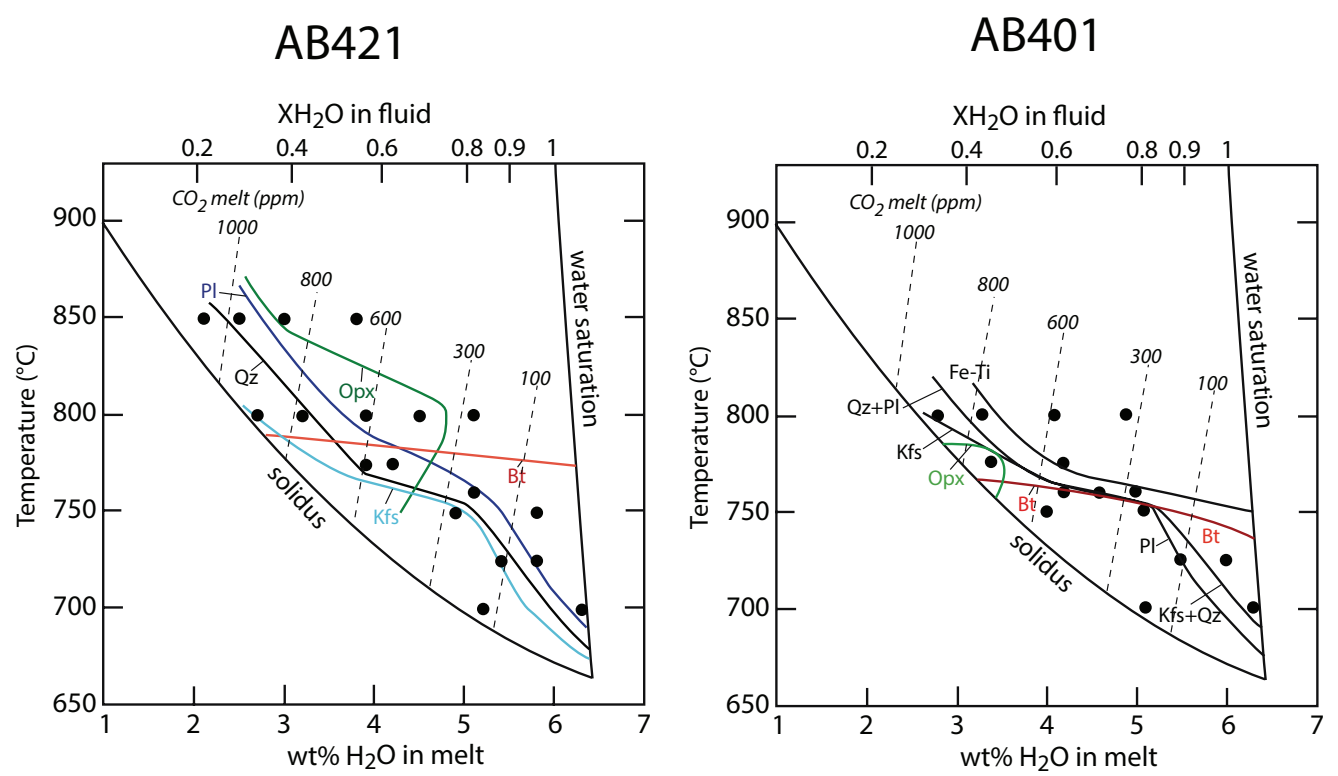

The proximate cause of these increased temperatures is the sharply reduced $\mathrm{H}_{2} \mathrm{O}$ activity. For 800 ppm $\mathrm{CO}_{2}$ in the melt and and a corresponding $X_{\mathrm{H}_{2} \mathrm{O}} \sim 0.4$ in the fluid, these temperatures rise by an additional $20-30{ }^{\circ} \mathrm{C}$. Several recent experimental studies on granite compositions have been conducted in the presence of a binary $\mathrm{H}_{2} \mathrm{O}-\mathrm{CO}_{2}$ fluid. These consistently show increases in eutectic and liquidus temperatures related to the lowered activity of $\mathrm{H}_{2} \mathrm{O}$ caused by the presence of $\mathrm{CO}_{2}$ in the system (Clemens and Wall 1981; Pichavant 1987; Keppler 1989; Ebadi and Johannes 1991; Holtz et al. 1992; Scaillet et al. 1995; Dall'Agnol et al. 1999; Scaillet and Evans 1999; Klimm et al. 2003, 2008; Bogaerts et al. 2006).

While dissolved $\mathrm{CO}_{2}$ in all cases is present in seemingly small quantities (a few hundreds of parts per million at most in silicic magmas), it does not imply that the magma was especially $\mathrm{CO}_{2-}$ poor. Petrological and geochemical arguments have led to the proposal that the Bishop Tuff magma was fluid-saturated prior to eruption (Wallace et al. 1995, 1999; Gualda and Anderson 2007), with amounts of fluid ranging up to nearly $6 \mathrm{wt} \%$ (Wallace et al. 1995, 1999). This, along with the restored fluid compositions of Wallace et al (1999), implies that a non trivial amount of $\mathrm{CO}_{2}$ was present in the reservoir, even in the most water-rich end member (EBT). For instance, for a magma containing $6 \mathrm{wt} \%$ fluid with a composition of $X_{\mathrm{H}_{2} \mathrm{O}}=0.97$ (close to the highest $X_{\mathrm{H}_{2} \mathrm{O}}$ inferred by Wallace et al. 1999), the bulk content of $\mathrm{CO}_{2}$ is $0.4 \mathrm{wt} \%$. For a magma with only $2 \mathrm{wt} \%$ exsolved fluid whose composition is $X_{\mathrm{H}_{2} \mathrm{O}}$ $=0.6$, the bulk $\mathrm{CO}_{2}$ content of the magma increases to $1.2 \mathrm{wt} \%$.

Experiments on haplogranitic compositions (e.g., Holtz et al. 1992) showed that the lower $\mathrm{H}_{2} \mathrm{O}$-activity caused by $\mathrm{CO}_{2}$ in the fluid induces a shift in the ternary minimum and eutectic compositions towards enrichment in Or relative to the Ab component, and higher eutectic crystallization temperatures Wholerock LBT is similarly enriched in $\mathrm{K}_{2} \mathrm{O} / \mathrm{Na}_{2} \mathrm{O}$, that is, normative $\mathrm{Or} / \mathrm{Ab}$, compared to EBT (Hildreth 1977). This provides further support for lower $\mathrm{H}_{2} \mathrm{O}$-activity in LBT caused by $\mathrm{CO}_{2}$ in the system and a higher temperature eutectic (Holtz et al. 1992). We conclude that the presence of $\mathrm{CO}_{2}$ in the LBT magma system is

F I G U R E 9. Experimental results for crystallization at $200 \mathrm{MPa}$ of two fused leucogranites AB421 and AB401 (as proxies for average LBT and EBT rhyolites, see Table 1; from Klimm et al. 2008), contoured for ppm $\mathrm{CO}_{2}$ in the melt. 
sufficient to account for the elevated temperatures $\left(780-820^{\circ} \mathrm{C}\right)$ extracted from magnetite-ilmenite thermometry (cf. Ghiorso and Gualda 2013; Gualda and Ghiorso 2013a; Gardner et al. 2014) in these least-evolved parts of the Bishop Tuff, notwithstanding their content of quartz, sanidine, and plagioclase. The counterargument for the minimal influence of $\mathrm{CO}_{2}$ developed by Gualda and Ghiorso (2013a, p. 769) was based on their finding of similar zircon saturation temperatures for EBT and LBT, a result that we consider untenable, as discussed above.

Despite a range in FeTi-oxide temperature from 700 to $\sim 780$ ${ }^{\circ} \mathrm{C}$ (Fig. 5), evolved, high- $\mathrm{SiO}_{2}$ EBT pumice shows only minimal compositional changes (in $\mathrm{TiO}_{2}, \mathrm{FeO}, \mathrm{CaO}, \mathrm{Ba}$ ) that could be attributed to crystal fractionation. Although some variability could be caused by post-eruption alteration, the whole-rock $\mathrm{K} / \mathrm{Na}$ atomic ratios of EBT are also a function of temperature (Fig.10). Again, this represents a shift in the ternary minimum composition that could be related to a change in $\mathrm{H}_{2} \mathrm{O}$-activity. It is arguable, however, whether a change in the melt content of $\mathrm{CO}_{2}$ (300 down to $6 \mathrm{ppm}$ ) is sufficient to drive this effect (Fig. 9). Certainly, the "eutectic" assemblage Qz-San-P1 in such an evolved rhyolite composition as EBT is only possible in the higher part of its temperature range if the activity of $\mathrm{H}_{2} \mathrm{O}$ is distinctly less than one (see below, under Implications).

\section{Presence of pyroxenes}

We view it as no coincidence that the allegedly too-high FeTi-oxide temperatures $\left(>770{ }^{\circ} \mathrm{C}\right)$ tend to be from samples that contain two pyroxenes. These are euhedral in outline, relatively homogeneous, and nearly uniform in intersample composition (Hildreth and Wilson 2007). Except at the highest temperatures (where we might call them phenocrysts), they are not in $\mathrm{Fe} / \mathrm{Mg}$ exchange equilibrium with the FeTi-oxides, the biotite, or the inferred silicic liquid (Evans and Bachmann 2013). We infer that the pyroxenes are a signal of hot conditions (e.g., $824 \pm 15$ ${ }^{\circ} \mathrm{C}$ from two-pyroxene thermometry, Frost and Lindsley 1992), that were inherited from a recharge magma that existed prior to its mixing with slightly cooler rhyolite above, an event that gave rise to the petrographic features that define LBT. Experiments on rhyolite and dacite compositions (Fig. 9; Clemens and Wall 1981; Dall'Agnol et al. 1999; Scaillet and Evans 1999; Klimm et al. 2003, 2008; Bogaerts et al. 2006) have shown that the crystallization of orthopyroxene requires relatively high temperature (generally $>750{ }^{\circ} \mathrm{C}$ ) or undersaturation in $\mathrm{H}_{2} \mathrm{O}$, or both. If the LBT magma was in fact stored on a millenium timescale at $730-750^{\circ} \mathrm{C}$ (Gualda et al. 2012b), we have to ask not only why euhedral orthopyroxene survived but why, in a fluid-saturated $\mathrm{H}_{2} \mathrm{O}$-rich rhyolite magma, there are no signs of corrosion of its crystal margins or growth of cummingtonite (or biotite?) at the expense of orthopyroxene ( \pm liquid) as, for example, in the Taupo rhyolites. It seems highly unlikely that orthopyroxene could survive for millenia (way beyond laboratory timescales) in an $\mathrm{H}_{2} \mathrm{O}$-rich vapor-saturated magma at $T \leq 740{ }^{\circ} \mathrm{C}$, which is the scenario advocated by Gualda and Ghiorso (2013a) and Gardner et al. (2014). Pyroxene was eliminated after one month in the experiments of Gardner et al. (2014). The pyroxenes survived because they were injected into the highly silicic melt pocket at the top of the Bishop Tuff reservoir only years to decades prior to eruption.

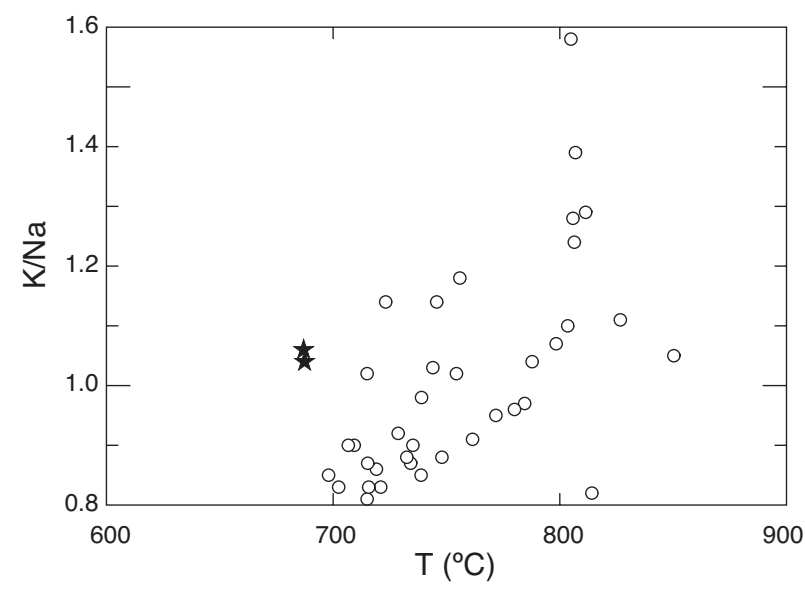

FIGURE 10. Diagram showing that whole-rock samples of hot (LBT and EBT) Bishop Tuff have higher atomic $\mathrm{K} / \mathrm{Na}$ than cooler $\left(\sim 700^{\circ} \mathrm{C}\right)$ EBT samples. Some of the higher K/Na samples may have been altered by post-eruption hydration (see text). Stars: see Figure 5 caption. Data from Hildreth and Wilson (2007).

\section{PhaSe EQUILIBRIUM EXPERIMENTS}

In petrological research on natural samples, we are seldom if ever in a position to prove in any specific case that a state of equilibrium was reached and frozen in. We use equilibrium criteria that are necessary but not sufficient, as in element partitioning diagrams. We might agree, though, that the greater the number of independent exchanges found to satisfy equilibrium criteria in any given case, the more likely is equilibrium (which could be system wide, partial, or local, e.g., Pichavant et al. 2007). Ultimately, laboratory reproduction of phase volumes and compositions at known temperature, pressure, and volatile fugacities offers a superior opportunity to resolve the question, but it is imperative that all intensive and extensive variables are a suitable match to the target of the investigation. Ideally, simulated phase diagrams such as rhyolite-MELTS should be consistent with corresponding experimental phase diagrams and mineral thermobarometry (including those used in the calibration).

Early Bishop Tuff pumice is composed of high-silica rhyolite with sparse phenocrysts of sodic plagioclase, as well as quartz, sanidine, biotite, magnetite, and rare ilmenite. Many of the pumice samples are close in whole-rock composition to haplogranite (Table 1). Their crystallization took place under vapor-saturated conditions (Wallace et al. 1995, 1999). At $200 \mathrm{MPa}$, the watersaturated solidus of haplogranite is $670^{\circ} \mathrm{C}$ (Pichavant 1987 ; Holtz et al. 1992; Scaillet et al. 1995; Johannes and Holtz 1996). For an EBT Plinian pumice (which accommodates some anorthite component), Scaillet and Hildreth (2001) found a water-saturated solidus of $680{ }^{\circ} \mathrm{C}$ at $200 \mathrm{MPa}$. Gualda and Ghiorso (2013b) computed crystallization temperatures with rhyolite-MELTS for water-saturated EBT and LBT at 175 and $250 \mathrm{MPa}$ and found almost identical eutectic crystallization temperatures for both (757-760 $\left.{ }^{\circ} \mathrm{C}\right)$. Compared to the Scaillet and Hildreth (2001) experiments and others on similar highly evolved natural granitic compositions (e.g. Klimm et al. 2003, 2008), their simulations showed a water-saturated eutectic temperature for EBT that seemed to be at least $50{ }^{\circ} \mathrm{C}$ too high. This reflected a problem 
with the entropy of the liquid as modelled in rhyolite-MELTS, and a down- $T$ correction of $40^{\circ} \mathrm{C}$ is now recommended (Gardner et al. 2014). The simulated temperatures for LBT, on the other hand, did not account for the presence of $\mathrm{CO}_{2}$ in the system. To counterbalance this omission, Gualda and Ghiorso (2013a, p. 763) suggested an up- $T$ offset on the order of $20^{\circ} \mathrm{C}$. In our opinion, this offset is inadequate.

Gardner et al. (2014) reported on hydrothermal laboratory experiments designed to reproduce the crystallization conditions and mineralogy of a sample of LBT rhyolite. The sample (AB6202) was from the Ig2NWb sequence (Fig. 1), with a crystallinity of $25.3 \mathrm{wt} \%$ (Pamukcu et al. 2012). The sample was crushed to $<100 \mu \mathrm{m}$ (but not fused at high temperature) and held under $\mathrm{H}_{2} \mathrm{O}$ saturated conditions at $T$ from 700 to $800{ }^{\circ} \mathrm{C}$ and $P$ from 50 to $200 \mathrm{MPa}$ for 4.8 to 25.9 days, with redox conditions inferred to be around NNO imposed on the sample by the vessel. Gardner et al. (2014, p. 9) found that orthopyroxene, almost a signature mineral for LBT, was "not stable experimentally" under any of the hydrous conditions used, and they concluded that LBT magma was stored at $\leq 740{ }^{\circ} \mathrm{C}$.

Three experiments at $785^{\circ} \mathrm{C}$ and 200-250 MPa (Gardner et al. 2014) were conducted under mixed volatile conditions $\left(\mathrm{H}_{2} \mathrm{O}\right.$ $\left.+\mathrm{CO}_{2}\right)$. The run with most $\mathrm{CO}_{2}(701 \pm 52 \mathrm{ppm}$ in product glass, and $3.91 \pm 0.23 \mathrm{wt} \% \mathrm{H}_{2} \mathrm{O}$ ) yielded orthopyroxene, sanidine, and oxide; the sanidine and oxide (magnetite?) both occur $65{ }^{\circ} \mathrm{C}$ higher than their respective liquidus curves under $\mathrm{H}_{2} \mathrm{O}$-saturated conditions at $200 \mathrm{MPa}$ (Gardner et al. 2014). These results are in general agreement with those of Klimm et al. (2008), which showed that orthopyroxene is stable at $\mathrm{H}_{2} \mathrm{O}_{\text {melt }}<4.5 \mathrm{wt} \%$ (Fig. 9). Nevertheless, Gardner et al. (2014) concluded that "at constant total pressure, the addition of trace amounts of $\mathrm{CO}_{2}$ to the melt phase would have little noticeable effect on the phase diagram." This conclusion seems to ignore the fact that, at the pressures considered, $700 \mathrm{ppm} \mathrm{CO}_{2}$ in the melt will be sustained by a mixed volatile fluid with $X_{\mathrm{CO}_{2}}$ and $X_{\mathrm{H}_{2} \mathrm{O}}$ around 0.5 (Fig. 9).

We interpret phase-equilibrium experiments to tell us that at $200 \mathrm{MPa}$ eutectic temperatures in the vicinity of $700{ }^{\circ} \mathrm{C}$ are to be expected for evolved granitic, $\mathrm{CO}_{2}$-free, $\mathrm{H}_{2} \mathrm{O}$-saturated compositions like those of the EBT, whereas eutectic temperatures of $\sim 800{ }^{\circ} \mathrm{C}$ will be the case for less evolved magmas like LBT containing 600-1000 ppm of $\mathrm{CO}_{2}$ in the liquid (corresponding however to significantly larger bulk $\mathrm{CO}_{2}$ contents, on the order of $1 \mathrm{wt} \%$, as explained above), in equilibrium with orthopyroxene (Fig. 9). EBT eutectic temperatures higher than $700{ }^{\circ} \mathrm{C}$ could be attributed to small amounts (6-300 ppm) of $\mathrm{CO}_{2}$ in the liquid, or to a process of partial melting in a cumulate mush zone underlying mainly liquid EBT (see below under Implications). These temperatures mimic rather well those indicated by FeTi-oxide and two-feldspar thermometry from the main suite of the BishopTuff, a very satisfying result from the viewpoint of equilibrium.

\section{MAGMA MIXING}

Evidence from the literature for magma recharge followed by magma mixing in the Bishop Tuff was reviewed in some detail by Evans and Bachmann (2013). The process has been found to be commonplace in upper crustal magma reservoirs. It has been invoked by a lengthy list of investigators for the Bishop Tuff and several other volcanic centers, some similar petrologically to the Bishop Tuff (e.g., Bandelier Tuff, Goff et al. 2014; Wolff and Ramos 2014). The process of magma mixing (recharge) is inherent to incrementally growing upper crustal magma reservoirs, as advocated by numerous authors in recent years (e.g., Lipman 2007; Annen 2009; Miller et al. 2011; Gelman et al. 2013; Laumonier et al. 2014).

In the Bishop Tuff, the petrographic evidence for magma mixing is far from hidden. In the late Bishop Tuff, we see two pyroxenes that equilibrated basically with a single magma composition (constant Mg-number), in association with FeTi-oxides and biotite that crystallized from magma showing evolving compositions (Evans and Bachmann 2013), together with partially resorbed quartz and sanidine, both of which underwent marginal growth and element enrichment due to contact at a late stage with less evolved, hotter $\mathrm{CO}_{2}$-bearing magma. Recognition of this recharge event is a prerequisite for avoiding misteps in the interpretation of many of the petrologic details in the Bishop Tuff, for example the melt inclusions.

Except for $\mathrm{K}_{2} \mathrm{O}$ and $\mathrm{Na}_{2} \mathrm{O}$, the measured contents of major elements in the melt inclusions of EBT and LBT samples are practically identical (Gualda et al. 2012a). As noted by Wallace et al. (1999), melt inclusions in EBT are almost identical in composition to whole-rock EBT, whereas in LBT there are significant differences in $\mathrm{SiO}_{2}, \mathrm{TiO}_{2}, \mathrm{FeO}, \mathrm{MgO}$, and $\mathrm{CaO}$ between WR and inclusions. These differences could be related to the greater proportion of crystals in typical LBT, but, given that $\sim 95 \%$ of crystals are feldspar (predominantly sanidine) and quartz (Hildreth and Wilson 2007), this explanation does not explain the differences in $\mathrm{FeO}$ and $\mathrm{MgO}$.

EBT is highly evolved silica-rich rhyolite (average $\mathrm{SiO}_{2}=77.6$ $\mathrm{wt} \%$ ), with only very small variations in most major and trace elements (Fig. 5). We plot $\mathrm{K}_{2} \mathrm{O}$ and $\mathrm{Na}_{2} \mathrm{O}$ (Fig. 10) with some reluctance, knowing the tendency for these constituents to undergo post-eruption alteration, typically with loss of $\mathrm{Na}$ (Hildreth and Wilson 2007). Nevertheless, whole-rock K/Na for EBT samples increases up-temperature from 0.81 to 0.95 (Fig. 10). K/Na atomic ratios of MI average 0.81 in EBT and range from 0.83 to 1.07 in LBT (the latter based provisionally on samples with $>80 \mathrm{ppm}$ $\mathrm{Ba}$ ). There is thus a trend in the $\mathrm{MI}$ analyses for $\mathrm{K} / \mathrm{Na}$ to be higher in the less evolved, higher FeTi-temperature (and higher zircon temperature) magma. This trend mirrors the one seen in the wholerock compositions. The comparison suggests that recharge LBT magma engulfed deep, "hot" rather than average $\left(\sim 730{ }^{\circ} \mathrm{C}\right)$ or low-temperature $\left(\sim 700^{\circ} \mathrm{C}\right)$ EBT magma. The growth of "bright rims" around the dark interiors of quartz and sanidine antecrysts that characterize LBT pumice tells us that only rim MI will give us the composition of LBT magma at the time (e.g., Roberge et al. 2013). By including all the MI in quartz, Gualda and Ghiorso (2013a, 2013b) found identical values of intensive parameters for EBT and LBT. Because the MI in CL-bright rims of quartz are few, small, decrepitated (Pamukcu et al. 2012), or hard to find, they have not been adequately sampled for their major or minor elements. When petrogenetic studies do not recognize these limitations (Ghiorso and Gualda 2013; Gualda and Ghiorso 2013a, 2013b), conclusions then conflict with FeTi-oxide and other thermometers that are supported by kinetics sufficiently fast to register late events in the magma sequence.

The mixing process resulted in matrix glass compositions in 
LBT less evolved than glass inclusions (Roberge et al. 2013), which is the inverse of simple, one-stage crystallization. According to Roberge et al. (2013): "the cores of quartz phenocrysts in LBT largely crystallized from more evolved melts at an earlier stage (EBT), and then were later incorporated into less evolved rhyolite melts from the underlying crystal mush zone." In addition, Chamberlain et al. (2014b) showed that CL bright rims of zircon in LBT have measurably smaller contents than dark interiors of incompatible elements such as U and HREE.

With a relatively late magma mixing event such as the one recorded in the Bishop Tuff, the petrologist sees parts of the system that accommodated and appear to have reached equilibrium (FeTi-oxides, biotite, plagioclase, and liquid), and other parts that either largely failed (pyroxenes) or only partially maintained equilibrium with the melt (quartz and sanidine). When we view whole-rock compositions of LBT, we must remember that these do not represent something that was ever $100 \%$ liquid. Wholerock compositions could have been enriched in $\mathrm{K}$ (by sanidine), $\mathrm{Si}$ (by quartz), or $\mathrm{Mg}$ and $\mathrm{Fe}$ (pyroxenes). Their crystal content (12-25 wt \%, Hildreth and Wilson 2007, Table 1) thus includes the products of in-situ crystallization (plagioclase, biotite, and oxides) as well as inherited crystals from the recharge (pyroxenes).

We prefer the hypothesis of partial melting of a cumulate mush (Deering et al. 2011; Bachmann et al. 2014; Wolff et al. 2015) to explain the compositional variations in minor elements in EBT (Fig. 5). By the melting of anhydrous solids, this process depletes the content of $\mathrm{H}_{2} \mathrm{O}$ in the liquid and thus maintains the eutectic nature of the mineral assemblage, with only small changes in major element contents (Wolff et al. 2015).

\section{IMPLICATIONS}

The temperature span of slightly more than $100^{\circ} \mathrm{C}$ indicated by FeTi-oxide thermometry for the Bishop Tuff encompasses attendant crystal-liquid fractionation and mixing in a shallow sub-volcanic magma reservoir influenced by a late-stage magma recharge event (leading to the mixed LBT) coming from below. The negative assessment of FeTi-oxide thermometry in the Bishop Tuff by Ghiorso and Gualda (2013) is flawed because it fails to recognize the range of $\mathrm{TiO}_{2}$ contents of the magma in the Bishop Tuff induced by fractionation/recharge. The positive slope of $a \mathrm{TiO}_{2}$ vs. temperature is not an indication of disequilibrium in the FeTi-oxides. Smooth correlations between FeTi-oxide thermometry and pumice and mineral compositions make it very unlikely the temperatures are seriously in error. The presence of 600-1000 ppm $\mathrm{CO}_{2}$ in quartz-rim melt inclusions and the corresponding lower $\mathrm{aH}_{2} \mathrm{O}$ enable us to reconcile published phase-equilibrium experiments with the $\sim 800{ }^{\circ} \mathrm{C}$ oxide temperatures. Calculated mole fractions of $\mathrm{H}_{2} \mathrm{O}$ in the LBT fluid are 0.6 or smaller, elevating eutectic and solidus temperatures by as much as $80-100{ }^{\circ} \mathrm{C}$.

On the basis of petrographic and geochemical observations accumulated over the last four decades, we favor a model that involves late-stage magma mixing and cumulate remobilization at the base of a crystal-poor high- $\mathrm{SiO}_{2}$ rhyolite cap extracted from a long-lived sub-volcanic silicic mush (see Hildreth 2004 for a cartoon). This model permits a coherent understanding of the spatial, temporal, microstructural, geochemical, and mineralogical features of the erupted products. These allow us to make sense of the complete $\log f_{\mathrm{O}_{2}}-T$ record of magma chamber conditions provided by the FeTi-oxides. Remarkable as it may seem to some, it would appear that among the mineral thermometers that have been applied to the Bishop Tuff, the ilmenite-magnetite thermometer remains virtually unmatched in its precision, accuracy, and inclusive coverage of magma chamber evolution.

\section{ACKNOWLEDGEMENTS}

We thank C.R. Bacon, J. Blundy, K.J. Chamberlain, G.A.R. Gualda, M. Loewen, J.B. Lowenstern, M. Pichavant, P.J. Wallace, and C.J.N. Wilson for critical comments on earlier versions of this manuscript. We also acknowledged the efforts of editor $\mathrm{K}$. Putirka to help shaping this manuscricpt for publication.

\section{REFERENCES CITED}

Anderson, A.T., Davis, A.M., and Lu, F. (2000) Evolution of Bishop Tuff rhyolitic magma based on melt and magnetite inclusions and zoned phenocrysts. Journal of Petrology, 41(3), 449-473.

Annen, C. (2009) From plutons to magma chambers: Thermal constraints on the accumulation of eruptible silicic magma in the upper crust. Earth and Planetary Science Letters, 284(3-4), 409-416.

Bachmann, O., Deering, C., Lipman, P., and Plummer, C. (2014) Building zoned ignimbrites by recycling silicic cumulates: insight from the $1,000 \mathrm{~km} 3$ Carpenter Ridge Tuff, CO. Contributions to Mineralogy and Petrology, 167(6), 1-13.

Bacon, C.R., and Hirschmann, M.M. (1988) Mg/Mn partitioning as a test for equilibrium between coexisting Fe-Ti oxides. American Mineralogist, 73, 57-61.

Baker, D.R. (2008) The fidelity of melt inclusions as records of melt composition. Contributions to Mineralogy and Petrology, 156(3), 377-395.

Bindeman, I.N., and Valley, J.W. (2002) Oxygen isotope study of the Long Valley magma system, California: isotope thermometry and convection in large silicic magma bodies. Contributions to Mineralogy and Petrology, 144, 185-205.

Blank, J.G., Stolper, E.M., and Carroll, M.R. (1993) Solubilities of carbon dioxide and water in rhyolitic melt at $8500^{\circ} \mathrm{C}$ and 750 bars. Earth and Planetary Science Letters, 119(1-2), 27-36.

Blundy, J., and Cashman, K. (2008) Petrologic Reconstruction of Magmatic System Variables and Processes. Reviews in Mineralogy and Geochemistry, 69(1), 179-239.

Boehnke, P., Watson, E.B., Trail, D., Harrison, T.M., and Schmitt, A.K. (2013) Zircon saturation re-revisited. Chemical Geology, 351(0), 324-334.

Bogaerts, M., Scaillet, B., and Auwera, J.V. (2006) Phase Equilibria of the Lyngdal Granodiorite (Norway): Implications for the origin of metaluminous ferroan granitoids. J. Petrology, 47(12), 2405-2431.

Chamberlain, K.J., Morgan, D.J., and Wilson, C.J.N. (2014a) Timescales of mixing and mobilisation in the Bishop Tuff magma body: perspectives from diffusion chronometry. Contributions to Mineralogy and Petrology, 168(1), 1-24.

Chamberlain, K.J., Wilson, C.J.N., Wooden, J.L., Charlier, B.L.A., and Ireland, T.R. (2014b) New Perspectives on the Bishop Tuff from Zircon Textures, Ages and Trace Elements. Journal of Petrology, 55(2), 395-426.

Chamberlain, K.J., Wilson, C.J.N., Wallace, P.J., and Millet, M.-A. (2015) Microanalytical Perspectives on the Bishop Tuff and its Magma Chamber. Journal of Petrology, 56(3), 605-640.

Clemens, J., and Wall, V.J. (1981) Origin and crystallization of some peraluminous (S-type) granitic magmas. Canadian Mineralogist, 79, 111-131.

Dall'Agnol, R., Scaillet, B., and Pichavant, M. (1999) An Experimental Study of a Lower Proterozoic A-type Granite from the Eastern Amazonian Craton, Brazil. Journal of Petrology, 40(11), 1673-1698.

Deering, C.D., Bachmann, O., and Vogel, T.A. (2011) The Ammonia Tanks Tuff: Erupting a melt-rich rhyolite cap and its remobilized crystal cumulate. Earth and Planetary Science Letters, 310(3-4), 518-525.

Ebadi, A., and Johannes, W. (1991) Beginning of melting and composition of first melts in the system Qz-Ab-Or-H2O-CO2. Contributions to Mineralogy and Petrology, 106(3), 286-295.

Evans, B.W., and Bachmann, O. (2013) Implications of equilibrium and disequilibrium among crystal phases in the Bishop Tuff. American Mineralogist, 98, 271-274.

Ferry, J.M., and Baumgartner, L. (1987) Thermodynamic models of molecular fluids at the elevated pressures and temperatures of crustal metamorphism. Reviews in Mineralogy and Geochemistry, 17(1), 323-365.

Frost, B.R., and Lindsley, D.H. (1991) Occurrence of iron-titanium oxides in igneous rocks. Reviews in Mineralogy, 25, 433-468.

(1992) Equilibria among Fe-Ti oxides, pyroxenes, olivine, quartz. Part II, Application. American Mineralogist, 77, 1004-1020.

Gardner, J., Befus, K., Gualda, G.A.R., and Ghiorso, M. (2014) Experimental constraints on rhyolite-MELTS and the Late Bishop Tuff magma body. Contributions to Mineralogy and Petrology, 168(2), 1-14.

Gelman, S.E., Gutierrez, F.J., and Bachmann, O. (2013) The longevity of large upper crustal silicic magma reservoirs. Geology, 41, 759-762.

Ghiorso, M.S., and Sack, R.O. (1991) Fe-Ti oxide geothermometry: thermodynamic formulation and the estimation of intensive variables in silicic magmas. Contribu- 
tions to Mineralogy and Petrology, 108, 485-510.

Ghiorso, M.S., and Evans, B.W. (2008) Thermodynamics of rhombohedral oxide solid solutions and a revision of the Fe-Ti oxide geothermometer and oxygenbarometer. American Journal of science, 308(9), 957-1039.

Ghiorso, M.S., and Gualda, G.A.R. (2013) A method for estimating the activity of titania in magmatic liquids from the compositions of coexisting rhombohedral and cubic iron-titanium oxides. Contributions to Mineralogy and Petrology, $165(1), 73-81$

(2015) $\mathrm{An}_{2} \mathrm{O}-\mathrm{CO}_{2}$ mixed fluid saturation model compatible with rhyoliteMELTS. Contributions to Mineralogy and Petrology, 169(6), 1-30.

Goff, F., Warren, R.G., Goff, C.J., and Dunbar, N. (2014) Eruption of reverse-zoned upper Tshirege Member, Bandelier Tuff from centralized vents within Valles caldera, New Mexico. Journal of Volcanology and Geothermal Research, 276(0), 82-104.

Gualda, G.R., and Anderson, A. Jr. (2007) Magnetite scavenging and the buoyancy of bubbles in magmas. Part 1: Discovery of a pre-eruptive bubble in Bishop rhyolite. Contributions to Mineralogy and Petrology, 153(6), 733-742.

Gualda, G.A.R., and Ghiorso, M.S. (2013a) The Bishop Tuff giant magma body: an alternative to the Standard Model. Contributions to Mineralogy and Petrology, 166(3), 755-775.

(2013b) Low-pressure origin of high-silica rhyolites and granites. The Journal of Geology, 121(5), 537-545.

Gualda, G.A.R., Ghiorso, M.S., Lemons, R.V., and Carley, T.L. (2012a) RhyoliteMELTS: A modified calibration of MELTS optimized for silica-rich, fluidbearing magmatic systems. Journal of Petrology, 53(5), 875-890.

Gualda, G.A.R., Pamukcu, A.S., Ghiorso, M.S., Anderson, A.T. Jr., Sutton, S.R., and Rivers, M.L. (2012b) Timescales of Quartz Crystallization and the Longevity of the Bishop Giant Magma Body. PLoS ONE, 7(5), e37492.

Hervig, R.L., and Dunbar, N.W. (1992) Cause of chemical zoning in the Bishop (California) and Bandelier (New Mexico) magma chambers. Earth and Planetary Science Letters, 111, 97-108.

Hildreth, W. (1977) The magma chamber of the BishopTuff: gradients in temperature, pressure, and composition. Ph.D thesis, University of California, Berkeley.

- (1979) The Bishop Tuff: evidence for the origin of the compositional zonation in silicic magma chambers. In C.E. Chapin, and W.E. Elston, Eds. Ash-Flow Tuffs, 180, p. 43-76. Geological Society of America, Special Paper 180.

- (1981) Gradients in silicic magma chambers: Implications for lithospheric magmatism. Journal of Geophysical Research, 86(B11), 10153-10192.

(2004) Volcanological perspectives on Long Valley, Mammoth Mountain, and Mono Craters: Several contiguous but discrete systems. Journal of Volcanology and Geothermal Research, 136, 169-198.

Hildreth, W.S., and Wilson, C.J.N. (2007) Compositional Zoning in the Bishop Tuff. Journal of Petrology, 48(5), 951-999.

Holloway, J.R. (1976) Fluids in the evolution of granitic magmas: Consequences of finite $\mathrm{CO}_{2}$ solubility. Geological Society of America Bulletin, 87(10), 1513-1518.

Holloway, J.R. (1987) Igneous fluids. Reviews in Mineralogy and Geochemistry, 17, 211-233.

Holloway, J.R., and Burnham, C.W. (1972) Melting relations of basalt with equilibrium water pressure less than total pressure. Journal of Petrology, 13(1), 1-29.

Holtz, F., Pichavant, M., Barbey, P., and Johannes, W. (1992) Effects of $\mathrm{H}_{2} \mathrm{O}$ on liquidus phase relations in the haplogranite system at 2 and $5 \mathrm{kbar}$. American Mineralogist 77, 1223-1241.

Johannes, W., and Holtz, F. (1996) Petrogenesis and Experimental Petrology of Granitic Rocks, 335 p. Springer-Verlag, Berlin.

Keppler, H. (1989) The influence of the fluid phase composition on the solidus temperatures in the haplogranite system $\mathrm{NaAlSi}_{3} \mathrm{O}_{8}-\mathrm{KAlSi}_{3} \mathrm{O}_{8}-\mathrm{SiO}_{2}-\mathrm{H}_{2} \mathrm{O}-\mathrm{CO}_{2}$. Contributions to Mineralogy and Petrology, 102(3), 321-327.

Klimm, K., Holtz, F., Johannes, W., and King, P.L. (2003) Fractionation of metaluminous A-type granites: an experimental study of the Wangrah Suite, Lachlan Fold Belt, Australia. Precambrian Research, 124(2-4), 327-341.

Klimm, K., Holtz, F., and King, P.L. (2008) Fractionation vs. magma mixing in the Wangrah Suite A-type granites, Lachlan Fold Belt, Australia: Experimental constraints. Lithos, 102(3-4), 415-434.

Laumonier, M., Scaillet, B., Pichavant, M., Champallier, R., Andujar, J. and Arbaret, L. (2014) On the conditions of magma mixing and its bearing on andesite production in the crust. Nature communications, 5.

Lesne, P., Scaillet, B., Pichavant, M., and Beny, J.-M. (2011) The carbon dioxide solubility in alkali basalts: an experimental study. Contributions to Mineralogy and Petrology, 162(1), 153-168.

Lindsley, D.H., Frost, B.R., Ghiorso, M.S., and Sack, R.O. (1991) Oxides Lie: The Bishop Tuff did not erupt from a thermally zoned magma body. EOS Transaction, American Geophysical Union, 72(17), 313.

Lipman, P.W. (2007) Incremental assembly and prolonged consolidation of Cordilleran magma chambers: Evidence from the Southern Rocky Mountain Volcanic Field. Geosphere, 3(1), 1-29.

Lipman, P.W., Dungan, M.A., and Bachmann, O. (1997) Comagmatic granophyric granite in the Fish Canyon Tuff, Colorado: Implications for magma-chamber processes during a large ash-flow eruption. Geology, 25(10), 915-918.

Lowenstern, J.B., Clynne, M.A., and Bullen, T.D. (1997) Co-magmatic A-type granophyre and rhyolite from the Alid volcanic center, Eritrea, Northwest Africa. Journal of Petrology, 38(12), 1707-1721.

Miller, C.F., Furbish, D.J., Walker, B.A., Claiborne, L.L., Koteas, G.C., Bleick, H.A., and Miller, J.S. (2011) Growth of plutons by incremental emplacement of sheets in crystal-rich host: Evidence from Miocene intrusions of the Colorado River region, Nevada, USA. Tectonophysics, 500(1-4), 65-77.

Newman, S., and Lowenstern, J.B. (2002) VolatileCalc: a silicate melt- $\mathrm{H}_{2} \mathrm{O}-\mathrm{CO}_{2}$ solution model written in Visual Basic for excel. Computers \& Geosciences, 28(5), 597-604

Pamukcu, A.S., Gualda, G.A.R., and Anderson, A.T. (2012) Crystallization Stages of the Bishop Tuff Magma Body Recorded in Crystal Textures in Pumice Clasts. Journal of Petrology, 53(3), 589-609.

Peppard, B.T., Steele, I.M., Davis, A.M., Wallace, P.J., and Anderson, A.T. (2001) Zoned quartz phenocrysts from the rhyolitic Bishop Tuff. American MIneralogist, $86,1034-1052$.

Pichavant, M. (1987) Effects of $\mathrm{B}$ and $\mathrm{H}_{2} \mathrm{O}$ on liquidus phase relations in the haplogranite system at 1 kbar. American Mineralogist, 72, 1056-1070.

Pichavant, M., Costa, F., Burgisser, A., Scaillet, B., Martel, C. and Poussineau, S (2007) Equilibrium scales in silicic to intermediate magmas: implications for experimental studies. Journal of Petrology, egm045.

Roberge, J., Wallace, P.J., and Kent, A.J.R. (2013) Magmatic processes in the Bishop Tuff rhyolitic magma based on trace elements in melt inclusions and pumice matrix glass. Contributions to Mineralogy and Petrology, 165(2), 237-257.

Rutherford, M.J., Sigurdsson, H., Carey, S., and Davis, A.M. (1985) The May 18 1980, eruption of Mount St. Helens, 1. Melt composition and experimental phase equilibria. Journal of Geophysical Research, 90, 2929-2947.

Scaillet, B., and Evans, B.W. (1999) The 15 June 1991 eruption of Mount Pinatubo. I. Phase equilibria and pre-eruption $P-T-f_{\mathrm{O}_{2}}-f_{\mathrm{H}_{2} \mathrm{O}}$ conditions of the dacite magma. Journal of Petrology, 40(3), 381-411.

Scaillet, B., and Hildreth, W. (2001) Experimental constraints on the origin and evolution of the Bishop Tuff. In K. Knesel, G.B. Bergantz, and J. Davidson, Eds Penrose Conference: Longevity and Dynamics of Rhyolitic Magma Systems. Geological Society of America.

Scaillet, B., Pichavant, M., and Roux, J. (1995) Experimental crystallization of leucogranite magmas. Journal of Petrology, 36, 663-705.

Silver, L., Ihinger, P., and Stolper, E. (1990) The influence of bulk composition on the speciation of water in silicate glasses. Contributions to Mineralogy and Petrology, 104(2), 142-162.

Tamic, N., Behrens, H. and Holtz, F. (2001) The solubility of $\mathrm{H}_{2} \mathrm{O}$ and $\mathrm{CO}_{2}$ in rhyolite melts in equilibrium with a mixed $\mathrm{CO}_{2}-\mathrm{H}_{2} \mathrm{O}$ fluid phase. Chemical Geology, 174, 333-347.

Thomas, J.B., and Watson, E.B. (2012) Application of the Ti-in-quartz thermobarometer to rutile-free systems. Reply to: a comment on: "TitaniQ under pressure: the effect of pressure and temperature on the solubility of Ti in quartz" by Thomas et al. Contributions to Mineralogy and Petrology, 164(2), 369-374.

Thomas, J.B., Watson, E.B., Spear, F.S. and Wark, D.A. (2015) TitaniQ recrystallized: experimental confirmation of the original Ti-in-quartz calibrations. Contributions to Mineralogy and Petrology, 169, 27-43.

Wallace, P.J., Anderson, A.T., and Davis, A.M. (1995) Quantification of pre-eruptive exsolved gas contents in silicic magmas. Nature, 377, 612-615.

Wallace, P.J., Anderson, A.T., and Davis, A.M. (1999) Gradients in $\mathrm{H}_{2} \mathrm{O}, \mathrm{CO}_{2}$, and exsolved gas in a large-volume silicic magma chamber: interpreting the record preserved in the melt inclusions from the Bishop Tuff. Journal of Geophysical Research, 104(B9), 20097-20122.

Wark, D.A., Hildreth, W., Spear, F.S., Cherniak, D.J., and Watson, E.B. (2007) Pre-eruption recharge of the Bishop magma system. Geology, 35(3), 235-238.

Watson, E.B., and Harrison, T.M. (1983) Zircon saturation revisited: temperature and composition effects in a variety of crustal magma types. Earth and Planetary Science Letters, 64, 295-304.

Wilson, C.J.N., and Hildreth, W. (1997) The Bishop Tuff: New insights from eruptive stratigraphy. Journal of Geology, 105, 407-439.

Wilson, C.J.N., Blake, S., Charlier, B.L. and Sutton, A.N. (2006) The 26.5 ka Oruani eruption, Taupo volcano, New Zealand: development, characteristics and evacuation of a large rhyolitic magma body. Journal of Petrology, 47, 35-69.

Wolff, J.A., and Ramos, F.C. (2014) Processes in caldera-forming high-silica rhyolite magma: $\mathrm{Rb}-\mathrm{Sr}$ and $\mathrm{Pb}$ isotope systematics of the Otowi Member of the Bandelier Tuff, Valles Caldera, New Mexico, USA. Journal of Petrology, 55(2), 345-375.

Wolff, J.A., Ellis, B.S., Ramos, F.C., Starkel, W.A., Boroughs, S., Olin, P.H., and Bachmann, O. (2015) Remelting of cumulates as a process for producing chemical zoning in silicic tuffs: a comparison of cool, wet and hot, dry rhyolitic magma systems. Lithos, 236-237, 275-286.

Zhang, Y. (1999) $\mathrm{H}_{2} \mathrm{O}$ in rhyolitic glasses and melts: Measurement, speciation, solubility, and diffusion. Reviews of Geophysics, 37(4), 493-516. 